\title{
Ecos da Guerra Civil espanhola na Grã-Bretanha através das publicaçooes do Left Book Club
}

\author{
Matheus Cardoso da Silva* \\ Universidade de São Paulo, São Paulo, São Paulo, Brasil
}

\section{RESUMO}

Este artigo pretende acompanhar a repercussão da Guerra Civil espanhola (1936-1939) na Grã-Bretanha, narrada através das publicaçóes do Left Book Club, fundado em Londres, em 1935. Ao longo de seus 13 anos de funcionamento, o LBC publicou 13 livros específicos sobre os assuntos da guerra, de um total de 255 títulos lançados, além de dois números especiais de sua revista oficial - Left News. A narrativa oferecida pelas publicaçóes do LBC ajudou na mobilização da opinião pública local, num momento em que o fascismo ainda não era considerado uma ameaça real ao império britânico, mas também demonstra como, devido às características de seu desenvolvimento e ao engajamento de inúmeros estrangeiros nos dois lados da guerra, o conflito teve, desde o início, um apelo transnacional. O livro se reafirmará tanto como suporte físico para a circulação de ideias, quanto como lugar de memória, capaz de contribuir com a construção da memória coletiva da guerra.

Palavras-chave: Guerra Civil espanhola; Left Book Club; História do livro; lugares de memória; circulação de ideias.

\section{RESUMEN}

Este artículo pretende acompañar la repercusión de la Guerra Civil Española (1936-1939) en Gran Bretańa, narrada por las publicaciones del Left Book Club, fundado en Londres en 1935. A lo largo de sus 13 años de existencia, el LBC publicó 13 libros específicos sobre los asuntos de la guerra, de un total de 255 títulos lanzados, además de dos números especiales de su revista oficial, Left News. La narrativa ofrecida por las publicaciones del LBC ayudó en la movilización de la opinión pública local, en un momento en que el fascismo todavía no era considerado una amenaza real al imperio británico, pero también demuestra cómo, debido a las características de su desarrollo y al envolvimiento de inúmeros extranjeros en los dos lados de la guerra, el conflicto tuvo, desde el principio, un apelo transnacional. El libro se reafirmará como soporte físico para la circulación de ideas y también como un lugar de memoria, capaz de contribuir con la construcción de la memoria colectiva de la guerra.

* Pesquisador da Universidade de São Paulo. E-mail: stardus_mat@yahoo.com.br. 
Palabras clave: Guerra Civil Española; Left Book Club; Historia del libro; lugares de memoria; circulación de ideas.

\section{ABSTRACT}

This article studies the repercussion of the Spanish Civil War (1936-1939) in Great Britain, narrated through the publications of the Left Book Club, founded in London in 1935. Throughout its 13 years of operation, the LBC has published 13 books on the subjects of War, of a total of 255 titles released, besides two special numbers of its official magazine - Left News. The paper demonstrates not only how the narrative offered by the LBC publications helped mobilize local public opinion when fascism was not yet perceived as a real danger to the Empire, but also, due to its developmental characteristics and the engagement of countless foreigners on both sides of the war, how the conflict had, from the outset, a transnational appeal. The book will reaffirm itself as much as a physical support for the circulation of ideas, as a place of memory, capable of contributing to the construction of the collective memory of war.

Keywords: Spanish Civil War; Left Book Club; History of the Book; Place of Memory; Circulation of Ideas.

\section{Introdução}

(...) "What's your proposal? To build the just city? I will. I agree. Or is it the suicide pact, the romantic Death? Very well, I accept, for I am your choice, your decision. Yes, I am Spain.”

O poema "Spain", de W. H. Auden, foi publicado inicialmente em formato de panfleto em Londres, em 20 de maio de 1937, após a visita do poeta a Espanha e mais tarde, revisado, sob o título "Spain 1937", incluído em seu livro Another Time (1940), publicado pela editora Faber \& Faber de Londres. Os valores arrecadados com as vendas foram repassados ao Spanish Medical Aid Committee, fundado em agosto de 1936, uma das várias organizaçôes humanitárias criadas nas Ilhas Britânicas para apoiar o lado republicano da guerra. O poema de Auden seria largamente repercutido, ajudando a angariar a atenção do público britânico para o que se passava na Espanha. Entre os comentadores de Auden, estava George 
Orwell, que o fez em seu livro de ensaios Inside the Whale, publicado pela editora Victor Gollancz Ltd, em 11 de março de 1940. Orwell, assim como Auden, fora testemunha ocular dos eventos espanhóis (contudo, diferente do poeta, Orwell lutou entre os republicanos, nas fileiras do comunista heterodoxo Partido Obrero de Unificación Marxista - POUM), relatando-os em primeira mão ao público britânico nos jornais da época.

A Guerra Civil espanhola foi desencadeada em 17 de julho de 1936, quando se configurou o assalto de um grupo de militares, apoiados por monarquistas e católicos, contra a Segunda República, eleita em 1931. Entre os conflitos em que a Grã-Bretanha não esteve diretamente envolvida, a guerra na Espanha teve a maior influência na vida política, cultural, social e na mobilização da opiniáo pública local no século XX, comparada apenas, talvez, com a Guerra da Bósnia, em 1992-1995, inclusive pelas dificuldades de compreensão de suas razóes. A Segunda República espanhola simbolizou a esperança das esquerdas britânicas na manutenção da democracia, no mesmo momento em que na Inglaterra se estabelecia a supremacia política dos conservadores através do "governo nacional" de Stanley Baldwin, visto pela esquerda como simpático ao fascismo. No outro extremo da política local, os políticos de direita invocavam os nacionalistas espanhóis para reivindicar maior retidáo quanto a questốes imperiais, como com o Movimento Nacional indiano. Com isso, a Espanha se tornou o "repositório de esperanças" para todos aqueles críticos do governo nacional, assim como parecia guardar a chave para as disputas da política interna britânica. ${ }^{1}$

A grande repercussão que a Guerra teve entre os britânicos demonstra com isso que, desde o início, o conflito tomou contornos transnacionais. $\mathrm{E}$ isso não apenas pelo fato de ser o maior conflito intraeuropeu no período posterior à Primeira Guerra Mundial, ensaiando a polarização política que daria sentido, em 1939, mesmo ano em que as forças republicanas são derrotadas, à Segunda Guerra Mundial. A Guerra Civil foi um conflito que transcendeu as fronteiras nacionais espanholas também por ter mobilizado milhares de estrangeiros que rumaram para a Espanha ao longo dos três anos de conflito para participar como combatentes, jornalistas (que noticiaram os acontecimentos para os quatro cantos do mundo), médicos e enfermeiros etc. A guerra foi um evento transnacional ainda em um terceiro aspecto: por ter mobilizado a opiniáo pública internacional, opondo diferentes setores sociais, sobre o apoio ou repúdio ao fascismo, quando também tomava os contornos de um movimento transnacional, tão grande quanto a resistência a ele. ${ }^{2}$

\footnotetext{
${ }^{1}$ BUCHANAN, Tom. Britain and the Spanish Civil War. Nova York: Cambridge University Press, 1997, p. 4-5 2 BERTONHA, João Fábio. Los fascismos en América Latina. Ecos europeos y valores nacionales en una perspectiva comparada. In: El fascismo en Brasil y América Latina. Ecos Europeos y desarrollos autóctonos. México (DF): Instituto Nacional de Antropología e Historia, 2013; CAPELATO, Maria Helena. Fascismo, uma ideia que circulou pela América Latina. In: SIMPÓSIO DA ASSOCIAÇÃO NACIONAL DE HISTÓRIA, 16., 1991, Rio de Janeiro, RJ. Anais..., p. 51-63; THURLOW, R. Fascism in Britain. From Oswald Mosley's Blackshirts to the National Front. Londres: I.B. Tauris, 2006; HOBSBAWM, Eric. Os intelectuais e o anti-fascismo. In: HOBSBAWM, Eric et al. História do Marxismo. São Paulo: Paz e Terra, 1989, p. 257-314. v. 9.
} 
Náo foi surpresa entáo que a Guerra chamou a atenção dos intelectuais, à esquerda e à direita, em um momento de acirramento das opiniôes e crescimento de sua participação nos debates públicos da sociedade britânica. A organização do Popular Front local, na esteira das Frentes Populares, definida como tática internacional de combate ao fascismo pelo VII Congresso da Internacional Comunista, em 1935, assim como a ascensão da British Union of Fascists, de Sir Oswald Mosley, fundada em 1932, cujos comícios e manifestaçôes públicas incitavam os britânicos ao debate - como naquela que resultou na "Batalha da Cable Street" — forçou os intelectuais a saírem de seus ambientes privados e interagir na crescente polarização da sociedade britânica. A guerra de narrativas sobre os acontecimentos na Espanha, desencadeada na imprensa britânica, mostraria o embate entre as perspectivas políticas locais em detrimento ao crescimento internacional do fascismo, enquanto o governo britânico insistia em uma política de neutralidade, apelando para os mecanismos diplomáticos da Liga das Naçóes que já haviam demonstrado serem fadados ao completo fracasso.

\section{O Left Book Club, as Frentes Populares e a Guerra Civil na Espanha}

O Left Book Club, fundado no mesmo ano de 1935, assumiu logo nos primeiros meses da guerra na Espanha a vanguarda das açóes organizadas pelo Partido Trabalhista em apoio aos republicanos espanhóis. Rapidamente, o LBC toma a forma de um aglutinador central das atividades dispersas dos diversos outros grupos que existiam entre as esquerdas através, especialmente, de uma tática organizada de produção, distribuição e circulação de livros, panfletos políticos e uma revista em que se concentrasse o debate produzido pela esquerda britânica naquele momento. A experiência prévia de Victor Gollancz como editor e a estrutura logística pronta, possibilitada pela editora Victor Gollancz Ltd., que existia desde 1928, deram as ferramentas necessárias para que o LBC e seus membros tomassem a frente na organização do Popular Front britânico. ${ }^{4}$

O LBC durou ativamente até 1948, resistindo aos anos mais difíceis da Segunda Guerra Mundial para a populaçáo que vivia na Inglaterra: dos bombardeios a Londres ao racionamento de papel, que durou até 1948 (talvez o maior desafio para a história da indústria

\footnotetext{
3 No dia 4 de outubro de 1936, a batalha da rua Cable, no East End de Londres, ocorreu quando a polícia metropolitana, escoltando uma marcha da British Union of Fascists, liderada por Mosley, entrou em confronto contra manifestantes antifascistas, incluindo judeus, comunistas, anarquistas e socialistas. A Batalha de Cable Street é um dos símbolos do movimento antifascista dentro do Popular Front britânico.

${ }^{4}$ Analisei a figura central de Victor Gollancz dentro do Popular Front britânico no artigo: SILVA, Matheus Cardoso da. Victor Gollancz: um editor socialista nos anos do Popular Front britânico. Mundos do Trabalho, v. 8, n. 16, jan./jun. 2016. Disponível em: <https://periodicos.ufsc.br/index.php/mundosdotrabalho/article/ view/1984-9222.2016v8n15p87>.
} 
tipográfica britânica) e a economia de guerra. ${ }^{5}$ Ao longo de seus 13 anos de funcionamento, o clube publicou 13 livros específicos sobre os assuntos da Guerra, de um total de 255 títulos de seu catálogo. No entanto, como veremos, é possível considerar que todos os livros publicados pelo clube na segunda metade da década de 1930 tiveram a influência da guerra na Espanha.

A criação do clube esteve ligada à conjuntura local de reação à crise que assolava a Inglaterra desde a década de 1920, um movimento que ganhou força com a organização do Popular Front. O LBC seria um de vários empreendimentos culturais criados na tentativa de organização de uma frente ampla entre socialistas, comunistas e liberais como reação ao avanço do fascismo na Europa, segundo a proposta elaborada pelo VII Congresso da Internacional Comunista, que definiu a tática frentista internacional, em um momento em que as ideias socialistas começam a circular em circuitos mais amplos da sociedade britânica.

Gollancz dividiu a fundação do LBC com outros dois intelectuais cujas biografias os destacam no período do entreguerras. Um dos cofundadores do LBC foi John Strachey (1901-1963) que integrou o Labour Party, a partir de 1923. Na década de 1930, Stratchey abandonou os trabalhistas para atuar como secretário-geral do New Party, fundado e dirigido por Oswald Mosley, em 1ํo de março de 1931. Pouco depois, quando Mosley se aproximou do fascismo e fundiu o partido na British Union of Fascists, em 1932, Strachey rompeu com Mosley e se filiou ao Communist Party of Great Britain (CPGB). No final da década de 1930, com a assinatura do Pacto Molotov-Ribbentrop, em 1939, e a invasão soviética da Finlândia, em março de 1940, Strachey se afastou gradualmente dos comunistas. Ele

\footnotetext{
${ }^{5} \mathrm{O}$ racionamento de bens de consumo, essenciais ou supérfluos, foi uma política adotada pelo governo britânico em diversos momentos da história inglesa no século XX, antes, durante e logo após guerras. No contexto da Segunda Guerra Mundial, na qual a Grã-Bretanha se engaja a partir de 3 de setembro de 1939, ao declarar guerra aos países do Eixo, o racionamento atingiu praticamente todos os setores da economia local, quase que automaticamente voltada ao esforço de guerra. Antes mesmo do início da Blitz nazista e dos bombardeios diários a diversas cidades britânicas, incluindo a capital Londres, a partir de 7 de setembro de 1940, a produção e o consequente consumo de papel já havia sido racionado pelo governo britânico — desde o início da guerra, um ano antes. Em 1942, sob o "Paper Control Order" n. 48, ditado pelo Cabinet, o consumo geral de papel passou a ser regulado pelo Ministry of Production. A partir de 1945, já com os nazistas derrotados, o consumo de papel para a produção dos jornais era reduzido a $25 \%$ do consumo anterior ao início da guerra, assim como era proibido o uso de papel em outros setores. Racionamento que afetou, obviamente, a indústria tipográfica britânica, representando, talvez, o maior desafio de sua história. George Orwell comentou os efeitos do racionamento geral de papel na edição de 20 de outubro de 1944 de sua coluna semanal para o jornal Tribune de Londres. À época, a quantidade de papel destinado para a produçấo de livros em todo o Reino Unido era de 22 mil toneladas. Em comparação, a quota de papel para o Stationary Office era de 100 mil toneladas e para o War Office, de 25 mil toneladas. Ou seja, o governo consumia, com os escritórios oficiais, mais do que toda a indústria tipográfica britânica junta. ORWELL, George. "As I Please”. Tribune, 20 October 1944. In: ORWELL, George. Complete Works of George Orwell. Peter Davison (Org.). Londres: Secker \& Warburg, v. 16. O racionamento de papel afetou diretamente também a produção da Victor Gollancz Ltd., representando grande desafio tanto para a editora privada de Victor Gollancz quanto, mais a frente para o Left Book Club. HODGES, Sheila. Gollancz: the Story of a Publishing House, 1928-1978. Londres: Littlehampton Book Services, 1979.
} 
se reaproximaria do Labour Party após o fim da Segunda Guerra Mundial, em 1945, permanecendo filiado ao partido até sua morte, em 1963. O terceiro cofundador do LBC foi o economista e cientista político Harold Laski (1893-1950), professor da London School of Economics e presidente do Labour Party entre 1945-46. Gollancz e Stratchey se dedicavam em tempo integral às atividades do LBC. Strachey, aliás, foi um dos maiores contribuidores do clube, escrevendo inúmeros artigos para a Left News e um total de 7 livros publicados pelo LBC. Recebia, inclusive, um salário semanal descontado no balanço geral do LBC por suas atividades. Laski, no entanto, conciliava suas outras ocupaçôes com o trabalho no comitê editorial do LBC, participando efetivamente em palestras e conferências, nas reunióes organizadas pelo clube, também escrevendo artigos para a revista Left News e publicando um livro pelo LBC.

Até a eclosão da Segunda Guerra Mundial, o clube oferecia a seus assinantes dois títulos mensais - o título normal de cada mês e o chamado "livro do mês", escolhido como uma edição especial para os membros - ao custo de 1/8 de libra por título, passando a disponibilizar um único título após $1939 .{ }^{6}$ Além da edição de títulos e a promoção de intelectuais de esquerda, o grupo distribuía mensalmente para seus assinantes a revista Left News, que contou com 128 números, publicados entre 1935 e 1947.7 Somado à circulação da revista, ficava facilitada a promoção de uma ampla rede de debates entre os principais grupos da esquerda britânica na década de 1930 .

Nas Ilhas Britânicas, o crescimento dos grupos aglutinados ao redor do LBC foi constante ao longo de seus primeiros anos de funcionamento. Na edição de julho de 1937 da revista Left News, por exemplo, há uma lista indicando o endereço de 600 "círculos" locais do clube (onde há referências sobre seçôes em Leeds, Liverpool, Wolverhampton, Cambridge etc.). ${ }^{8}$ $\mathrm{Na}$ Left News de janeiro de 1938, o número de círculos ligados ao clube é anunciado como o de mais de 800 "local circles" — ou seja, 200 a mais do que os 600 anunciados na ediçâo de julho de 1937. Já no número 36, de março de 1939, era anunciado o crescimento para 1.500 grupos em torno do LBC, ${ }^{9}$ o que mostra um crescimento exponencial do clube nesse período. ${ }^{10}$ No ápice de seu funcionamento, em 1938, o clube aglutinava a soma de 57 mil membros associados, em mais de 1.500 seçôes espalhadas por várias cidades na Inglaterra e

\footnotetext{
${ }^{6}$ As informaçóes sobre a organização do LBC e seu funcionamento podem ser lidas, por exemplo, na resposta (MSS.157/3/LB/2/6.i), de 21 de novembro de 1956, à carta de Roy Hill (MSS.157/3/LB/2/5 de 20 de novembro de 1956), solicitando detalhes sobre a organização do LBC para um livro sobre o tema. Victor Gollancz papers, Modern Records Center. University of Warwick.

${ }^{7}$ A coleção da University of Sheffield reúne também boa parte das ediçóes da revista Left News em microfilme. Nela estão disponíveis os números 15(1937) e 21 a 128 (1938 a 1947), faltando então os primeiros 14 números da revista. Devo agradecer toda a ajuda despendida pelo staff da Special Collection da Western Bank Library, da University of Sheffield, no apoio a minha pesquisa entre seus arquivos, em especial a seu arquivista, Chris Loftus.

8 "Left Book Club Summer School". Left News, n. 14, 15 de julho de 1937, p. 436.

${ }^{9}$ Left News, n. 36, março de 1939, p. 1119.

${ }^{10}$ Left News, n. 21, 21 de janeiro de 1938, p. 704.
} 
nas Ilhas Britânicas, além de 15 seçóes internacionais, com representaçóes em todos os continentes. Pelo LBC, publicaram alguns dos intelectuais mais influentes daquela geração britânicos e estrangeiros. O clube os mobilizou ainda em eventos humanitários, aulas para a educação das classes trabalhadoras, comícios e debates públicos. Fatores que davam ao LBC a condição de uma das organizações políticas mais importantes do período.

A experiência inovadora do LBC em Londres motivou ainda a criação de outros clubes pelo mundo, por exemplo, na Austrália, Canadá, China, África do Sul, Índia, Noruega, Bélgica, França, Palestina, Chile etc. ${ }^{11}$ Além da possibilidade da circulação das edições produzidas pelo LBC, essas redes internacionais demandavam também a disseminação da Left News por entre os leitores internacionais, ${ }^{12}$ criando assim um grande circuito com a finalidade de difusão dos debates da esquerda e a promoção do socialismo.

Esse é o caso, por exemplo, do The Current Affairs Group, o braço local do LBC na Rodésia do Sul. O grupo foi fundado em 1938 sob influência direta de Victor Gollancz para apoiar a causa republicana da Guerra Civil espanhola. Junto com o jornal comunista sulafricano Guardian, o The Current Affairs Group era responsável por disseminar as ideias socialistas entre a populaçáo negra, segregada pelo apartheid. No entanto, as discordâncias entre a atuação do Partido Comunista da África do Sul quanto à formação de um Partido Comunista da Rodésia do Sul (que carregava consigo as ideias de libertação nacional) levaram membros locais à criação de um grupo mais organizado, sob a alcunha de Left Club, do qual a escritora britânica Doris Lessing foi secretária ${ }^{13}$

No ápice do conflito espanhol, o engajamento de Victor Gollancz, editor-chefe do LBC e de todo o aparato do clube, ajudou não apenas a tornar a guerra ainda mais presente para os britânicos, difundindo o conflito e suas versóes por entre sua rede nacional e internacional, como também ofereceu relatos em primeira mão de seus desdobramentos. O clube mergulhara de cabeça na guerra de narrativas em confronto na opinião pública britânica. Gollancz teve papel-chave também com ajuda efetiva ao lado republicano, empregando o aparato do LBC em campanhas para arrecadação de ajuda humanitária para as vítimas da guerra, transformando o conflito efetivamente numa causa transnacional.

\footnotetext{
${ }^{11}$ Ver, por exemplo, a carta de Arthur Key (da Middle East Press service, situada em Londres) para Gollancz, de 11 de junho de 1945. (MSS.157/3/LB/1/2, Victor Gollancz Papers, Modern Records Center, University of Warwick)

${ }^{12}$ Ver, por exemplo, a carta do padre R. Conesa (MSS.157/3/LB/1/13, Victor Gollancz Papers, Modern Records Center, University of Warwick).

${ }^{13}$ Sobre as ligaçôes do LBC na Rodésia do Sul, há referências esparsas no livro no capítulo 4, "The impacto of anti-Communism on White Rhodesian political culture, 1920s-1980", assinado por Donal Lowry, (p. 84-110) do livro de Sue Onslow, Cold War in Southern Africa: White Power, Black Liberation. Nova York: Routledge, 2009.
} 


\section{Do isolacionismo ao engajamento: os efeitos da guerra na Espanha para o campo das esquerdas britânicas}

Entre os britânicos, a guerra teve o papel-chave na remobilização da opinião pública, dominada desde o fim da Primeira Guerra Mundial pelo pacifismo e pelo isolacionismo, que dirigia também a política exterior britânica, muito mais interessada na manutenção do Empire do que no envolvimento direto nas questóes da política continental. A guerra na Espanha empurrou à polarizaçáo dos jornais, dos políticos e dos intelectuais rumo a uma tomada de posição sobre o assalto do "Movimiento Nacional" contra a Segunda República: ou se apoiava os republicanos, como o fez toda a esquerda - se fracionando ao longo do conflito por disputas internas - ou se apoiava os nacionalistas, como o fez a direita e os simpáticos ao fascismo, tal qual Mosley. A política "neutra" dos governos francês e inglês tentando estabelecer um diálogo diplomático para o conflito no âmbito da Liga das Nações, ainda que tivera certa repercussão positiva na opinião pública inglesa inclusive entre os comunistas — já se mostrara um completo fracasso na França, cindindo o governo de Leon Blum. ${ }^{14}$

Ao contrário da pouca repercussáo dentro do governo conservador de Stanley Baldwin, na sociedade civil, o conflito mobilizou inúmeros discursos, encontros, reuniôes, passeatas, notas na imprensa, em panfletos distribuídos pelas cidades inglesas etc. Simbolicamente, representou um momento importante da educação de jovens militantes que viram uma causa pela qual lutar. No campo das esquerdas, com isso, a Guerra na Espanha permitiu ao CPGB desafiar o Labour Party depois de anos de isolacionismo sectário.

É preciso ter em conta, nesse sentido, a força do pacifismo para a política britânica do entreguerras, incluindo entre as esquerdas. Desde o final da Primeira Guerra Mundial, as ideias pacifistas foram centrais na maioria dos partidos britânicos. Para o Labour Party, o pacifismo foi um forte condutor de suas decisóes até 1935, quando assume como secretário-geral Hugh Dalton, que defendia o rearmamento britânico contra a Alemanha e a Itália. Mesmo assim, o Labour Party continuou votando contra o rearmamento até 1937. O movimento pacifista britânico era liderado pela Peace Pledge Union (PPU), fundado pelo

\footnotetext{
${ }^{14}$ O Pacto de Não Intervençáo foi apresentado pelo embaixador francês na Liga das Naçôes, Charles de Chambrun, em 3 de agosto de 1936, e aceito imediatamente pelos britânicos. No dia 7 de agosto, a França declara unilateralmente a vigência do Pacto, antes mesmo da reposta de alemães e soviéticos. A adesão de outros países, depois da iniciativa francesa, é gradual: Bélgica, Polônia e Tchecoslováquia assinam logo em seguida. A Alemanha adere ao pacto em 9 de agosto; Portugal, no dia 13. Desde o dia 5 de agosto, o governo dos Estados Unidos havia deixado claro que seguiria a política da não intervenção, apesar de não aderir ao pacto. Isso se confirma quando a Companhia Glenn L. Martin se recusa a vender oito bombardeios à Força Aérea Republicana espanhola. No dia 23 de agosto, a URSS adere ao pacto, apesar de o Pravda anunciar que Stalin já havia enviado armas e apoio financeiro aos republicanos. No dia 24 de agosto, os alemães assinam o pacto e concordam em náo comercializar nenhum equipamento militar ou enviar tropas para a Espanha. $\mathrm{O}$ México, ao contrário, seria o primeiro país a declarar apoio irrestrito ao governo republicano.
} 
Ecos da Guerra Civil espanhola na Grã-Bretanha através das publicaçốes do Left Book Club

Matheus Cardoso da Silva

reverendo Dick Sheppard, em maio de 1936. Em 1940, ela contava com 136 mil membros, apesar da morte de seu líder em 1937. A PPU substituiu outros movimentos anteriores, como a No More War Movement, que organizou manifestaçóes pacifistas quando da irrupçáo da Guerra Civil na Espanha. ${ }^{15}$

O CPGB também organizou um movimento pacifista como tática de combate ao fascismo. A campanha internacional financiada pelo Comintern $^{16}$ foi a maneira com que o CPGB se posicionou na Liga das Naçóes. Através dos debates sobre o pacifismo como meio de articulação do movimento antifascista, o CPGB organizou inúmeros grupos de debates em que discutia também o recrutamento para as Brigadas Internacionais ${ }^{17} \mathrm{e} o$ apoio humanitário para as vítimas da guerra. Curiosamente, no entanto, o primeiro grupo de voluntários internacionais a se engajar na Espanha em defesa da República foi a Tom Mann Centuria, criada em 10 de setembro de 1936, por iniciativa do CPGB, através dos contatos entre Harry Pollit, secretário-geral do partido, e Tom Wintringham. ${ }^{18}$ A figura de Wintringham, aliás, foi fundamental

\footnotetext{
${ }^{15}$ BUCHANAN, Tom. Britain and the Spanish Civil War, op. cit., p. 67.
}

${ }^{16} \mathrm{O}$ Comintern é o nome com o qual se designa a Terceira Internacional comunista. A organização foi fundada por Lenin, através do Partido Comunista da União Soviética, em maio de 1919, com o objetivo de reunir todos os partidos comunistas internacionais em uma direção centralizada, a partir dos soviéticos. $\mathrm{O}$ Comintern apresentou em suas resoluçóes iniciais alguns objetivos programáticos claros: lutar pela superação do capitalismo; o estabelecimento da ditadura do proletariado e da República Internacional dos Sovietes; a completa abolição das classes e a realização do socialismo como transição para a sociedade comunista, através da completa abolição do Estado e da derrubada da burguesia internacional. Ver, por exemplo, LENIN, Vladimir. Speech at the Opening Session of the Congress. First Congress of the Communist International. 2 de março de 1919. Lenin Collected Works, v. 28, p. 455-477. Disponível em: <https://www.marxists.org/ archive/lenin/index.htm>. Lenin Internet Archive. 2000.

${ }^{17}$ As Brigadas Internacionais foram formadas no mês de setembro de 1936, por Josef Stalin, a partir da ideia de Maurice Thorez, do Partido Comunista Francês, para organizar batalhôes de voluntários internacionais que seriam enviados a Espanha para ajudar a defender o governo republicano contra os nacionalistas e seus apoiadores internacionais. O centro de recrutamento das Brigadas Internacionais foi constituído em Paris e o centro de treinamento em Albacete, na Espanha. Eram divididas em sete brigadas, cada uma com uma média de quatro batalhóes, organizados por nacionalidade ou língua a fim de facilitar a comunicação e o comando. Entre esses agrupamentos estavam a Abraham Lincoln Brigades (da XV Brigada), formada por voluntários dos Estados Unidos e Canadá, mas que teve voluntários de outros países, incluindo chineses; o British Battalion (da XV Brigada), formada por voluntários da Inglaterra, Escócia, País de Gales e Irlanda; a Djakovich Battalion (da 129 Brigada), formada por voluntários búlgaros; o Dimitrov Battalion (da XV Brigada), formada por voluntários gregos e diversas nacionalidades balcânicas; a Thalmann Battalion (da XII Brigada), formada por voluntários alemães, austríacos, suíços e escandinavos, muitos de origem judaica; a Garibaldi Battalion (da XII Brigada), formada por italianos etc. Além dessas nacionalidades, se engajaram nas fileiras das Brigadas muitas outras, entre africanos, latino-americanos e asiáticos. As Brigadas foram dissolvidas em setembro de 1938 pelo primeiro-ministro espanhol Juan Negrin, com o objetivo de angariar apoio internacional das democracias liberais através do Comitê de Não Intervenção (1936-1939). Ao longo dos dois anos de atuação, as Brigadas engajaram cerca de 35 mil voluntários, dos quais 15 mil foram mortos em combate. Sobre a história do British Battalion e dos voluntários britânicos, ver por exemplo a International Brigades Memorial Trust, repositório on-line que preserva a memória dos voluntários que combateram na Espanha em apoio aos republicanos espanhóis. Disponível em: <http://www.international-brigades.org.uk/>.

${ }^{18}$ A Tom Mann Centuria foi batizada em homenagem a Thomas Mann (1856-1941), destacado líder sindicalista e orador do movimento trabalhista britânico no final do século XIX, nascido no subúrbio de Coventry, 
para a popularização dos debates políticos na década de 1930 na sociedade britânica, e não apenas no campo das esquerdas. Veterano da Primeira Guerra Mundial, jornalista, marxista e um dos fundadores do CPGB (1923), Wintringham se destacou como uma das figuras mais radicais da opinião pública britânica na década de 1930, sendo inclusive encarcerado por suas atividades políticas. Ajudou a fundar o Daily Worker, em 1930, publicação oficial do CPGB, e foi um dos que mais contribuiu com a revista teórica do partido, a Labour Monthly, editada por Rajani Palme-Dutt, ${ }^{19}$ na qual se destacou como analista de assuntos militares. Em 1936, logo depois da conflagração da guerra, Wintringham desembarcou em Barcelona, como correspondente do Daily Worker até setembro, quando, após as conversas com Pollit, reuniu a Tom Mann Centuria a um agrupamento maior de voluntários britânicos que deram origem ao British Battalion, o qual comandaria pouco depois, ligado às Brigadas Internacionais. Wintringham teria ainda um papel-chave nos debates públicos da Inglaterra no contexto da Guerra Civil espanhola, através da defesa, em seus artigos, da necessidade da preparação das cidades e da população inglesa contra os ataques aéreos, especialmente depois do bombardeio à vila basca de Guernica por avióes da Luftwaffe. Os argumentos de Wintringham seriam fundamentais para o crescimento do movimento ARP (Air Raid Precautions), ao qual o LBC se engajaria de maneira fundamental, como veremos a seguir.

Os resultados do engajamento do CPGB com a Guerra Civil na Espanha foram claros para o crescimento do partido no correr da década de 1930. No início da década, o partido contava com 1.356 filiados. Na metade da década de 1930, o partido emergia de um longo período de isolamento sectário - entre 1929 e 1933, quando havia acusado os outros partidos de esquerda de "social fascismo". Em 1935, após o VII Congresso da Internacional Comunista e a definição da Frente Popular como estratégia de combate ao fascismo, os comunistas passaram a participar mais abertamente dos debates na sociedade e de demonstraçóes públicas para quebrar o estigma em torno do movimento comunista na sociedade britânica. Em fevereiro de 1935, o número de filiados ao partido chegou aos 6.500 membros, para, em 1936, alcançar 11 mil. Em 1938, atingiria 15.570 filiados e, em julho de 1939, 17.750. ${ }^{20}$

Inglaterra. Ativo na organização de diversas greves locais, Mann integrou também comissóes oficiais por reformas trabalhistas, como a Roy Commission on Labour entre 1891 e 1894. Mann foi também um dos fundadores do Independent Labour Party, se tornando secretário-geral do partido em 1894 e concorrendo pelo partido nas eleiçôes gerais de 1895, sem sucesso. Colaborou ainda na fundação da International Transport Workers' Federation, em 1896, organizaçáo sindical internacional com sede em Londres e que aglutina diversos sindicatos de trabalhadores dos transportes no mundo todo, com uma estimativa atual de 5 milhóes de membros filiados.

${ }^{19}$ A Labour Monthly, aliás, dedicou à Guerra Civil espanhola vários dos artigos publicados na revista ao longo da segunda metade da década de 1930. Os primeiros textos apareceram no n. 9, v. 18, de setembro de 1936, incluindo o editorial, assinado por Palme-Dutt (p. 523-533), que apresentou a posiçáo oficial do CPGB em relação ao conflito. Ver Labour Monthly Index. Marxist Internet Archives. Disponível em: <http://www.marxistsfr.org/history/international/comintern/sections/britain/periodicals/labour_monthly/1930s.htm\#1936>. ${ }^{20}$ BUCHANAN, Tom. Britain and the Spanish Civil War, op. cit., p. 69-70; RODDEN, John. On the Political Sociology of Intellectuals: George Orwell and the London Left Intelligentsia of the 1930s. Canadian 
Muitos desses novos membros eram advindos de estratos da classe média, onde inúmeros intelectuais se encontravam socialmente colocados.

O início da participação em massa dos intelectuais na vida política britânica teve um efeito imediato nas ideias que circulavam na esfera pública britânica. $\mathrm{O}$ socialismo, então restrito ora aos sindicatos dos centros industriais britânicos, ora aos clubes fechados dos intelectuais universitários, durante o ápice da crise social da década de 1930, torna-se o leitmotiv para a fundação de inúmeras organizaçóes e movimentos artísticos - entre grupos de teatro, produtoras cinematográficas, editoras, além de revistas e jornais. Grupos que tomavam corpo em um movimento coletivo, reivindicando novas formas de organização política para a Inglaterra, todas concebidas através dos ideais revolucionários socialistas. E o LBC rapidamente assumiu a vanguarda desse movimento, atingindo já em 1938 (ou seja, apenas três anos após sua fundação) a soma de 57 mil associados, números anunciados na publicação oficial do clube, a revista Left News, servindo como guarda-chuva para muitos desses intelectuais e suas atividades culturais. Cifras que indicavam o LBC como a maior organização política da Grã-Bretanha à época. ${ }^{21}$

O apelo pelo "United Front" dentro da Grã-Bretanha não foi respondido pelo Labour Party, assim como ocorrera na Espanha. Por isso, Henry Pollit, secretário-geral do CPGB, reorganizou o envio de fundos de ajuda humanitária captada entre os comunistas, antes enviados para um fundo comum administrado pelo Labour Party. ${ }^{22}$

Três foram as maiores razóes para os desentendimentos entre o CPGB e o Labour Party em relação à Guerra civil espanhola: em primeiro lugar, os comunistas eram completamente contrários à política de não intervenção adotada pelos trabalhistas. Primeiro, endossado por Moscou e pelo Comintern, o Pacto de Não Intervenção visava manter a paz entre as nações europeias, mesmo que náo houvesse acordo sobre outros temas, e ao mesmo tempo enfraquecer os rebeldes, o que não ocorreu na verdade. Segundo, Henry Pollit insuflou o movimento trabalhista pelo apoio à República espanhola, coisa que o Labour Party não estava disposto a fazer. E terceiro, a decisão da organização das Brigadas Internacionais afastou definitivamente os dois partidos, cindindo o apoio do movimento trabalhista daquele organizado pelos comunistas. E a formação do British Battalion nas Brigadas Internacionais foi

Journal of Sociology/Cahiers canadiens de sociologie, v. 15, n. 3, Summer, 1990, p. 257. Disponível em: <http://www.jstor.org/stable/3340915?seq=1\#page_scan_tab_contents>. Acesso em: 15 mar. 2008.

${ }^{21}$ Como indicou relatório da Scotland Yard de 17 de janeiro de 1938. (Pasta HO 144/21529. Home Office papers. The National Archives, Kew, Inglaterra) O crescimento do Clube na década de 1930, dentro e fora da Inglaterra, foi alvo de preocupação direta de órgáos do Estado britânico, como o Home, o Foreign Office e a Scotland Yard, que acompanharam passo a passo as atividades do LBC, especialmente antes da eclosão da Segunda Guerra Mundial. A preocupação do Estado britânico girava em torno dos contatos de Gollancz com membros do National Indian Congress e outros contatos com as colônias. A ponto de todos esses órgáos estatais produzirem material constante sobre as atividades do Clube no período. Tal material, ainda pouco explorado, me apresentou outra possibilidade de estudos das relaçóes internacionais do LBC com o universo colonial, o qual pretendo explorar em pesquisa futura de pós-doutorado.

${ }^{22}$ BUCHANAN, Tom. Britain and the Spanish Civil War, op. cit., p. 70. 
a maior prova da capacidade de organização do CPGB após as proibiçôes de recrutamento dadas pelo governo britânico em 1937.

\section{A Guerra Civil narrada através das publicações do Left Book Club}

Foi então nesse duplo cenário de disputas narrativas - um mais geral, da opinião pública, em que as versôes da guerra eram apresentadas, incluindo as perspectivas da direita, e outro mais específico, do campo das esquerdas - que o LBC se inseriu. A narrativa da guerra construída pelas publicaçóes do clube ofereceriam, como todas as outras, um ponto de vista específico - no caso, pró-República - dos eventos na Espanha, apresentados sob as múltiplas perspectivas de seus diferentes autores. É interessante notar, por exemplo, que alguns deles eram apresentados aos leitores como "testemunhas oculares" dos eventos. O que reforçava o tom de "veracidade" de sua narrativa perante o público, funcionando também como recurso de poder (o "testemunho" como sinônimo de veracidade factual). Os livros editados pelo LBC podem ser entendidos então não apenas como um suporte físico que dâo materialidade à cultura de uma época, como afirmou Chartier (2002), fazendo circular na imprensa as narrativas sobre os eventos da Guerra Civil espanhola na sociedade britânica. Esses suportes podem ser estudados, também na perspectiva oferecida por Pierre Nora (1984), como um "lugar de memórias", por caracterizarem-se como um espaço discursivo onde a memória é institucionalizada entre as diversas linhas ideológicas que disputavam as narrativas da guerra diante do público local. ${ }^{23}$

No século XX, o grande problema epistemológico que emerge diante da relevância da memória para a historiografia é sua função política nos Estados e nas sociedades. E as experiências autoritárias e totalitárias são, sem dúvida, as mais emblemáticas nesses processos. É largamente conhecido e estudado o papel que, por exemplo, as várias formas de censura (inclusive da literatura, do cinema e das artes em geral) desempenharam como mecanismo institucional de construção de um discurso monológico nos regimes autoritários. ${ }^{24} \mathrm{Ou}$, o papel da propaganda política na construção de um arcabouço simbólico e iconográfico de referências para a coletividade. Ou ainda, o papel dos meios de comunicação de massa - o rádio, o jornal, o cinema — na "homogeinização" ideológica das consciências individuais, sobre um conjunto comum de referências simbólicas. Disputas que, inevitavelmente, tomam como campo de batalha o universo simbólico da sociedade — ou, todos aquelas referências que, no espaço público, atribuem significado coletivo à imaginação social..$^{25}$

\footnotetext{
${ }^{23}$ CHARTIER, Roger. Os desafios da escrita. São Paulo: Editora da Unesp, 2002; e As origens cuturais da Revolução Francesa. São Paulo: Editora da Unesp, 2003; NORA, Pierre. Entre memóire et históire, la problématique des lieux. In: NORA, Pierre (Org.). Le lieux de memóire. Tome I (La Republic). Paris: Galllimard, 1984.

${ }^{24}$ SARLO, Beatriz. Literatura y autoritarismo. In: MASSUH, Gabriela (Org.). Formas no políticas del autoritarismo. Buenos Aires: Goethe Institut, 1991.

${ }^{25}$ BACZKO, Bronislaw. Imaginação social. In: Enciclopdia Einaudi, v. 5. Vila da Maia: Imprensa Nacional/ Casa da Moeda, 1985, p. 333-396.
} 
A conceitualização de Nora sobre os "lugares de memória" vai considerar as funçôes "sociais" da memória como mecanismo de afirmação dos vários grupos sociais nos Estados contemporâneos. Nora também identificará um processo de "produção em massa" de "discursos de memória" (aqui, "discursos" no plural), como característica das tensōes sociais contemporâneas. ${ }^{26}$

Outra tese fundamental na análise de Nora será sua ideia da ampliação dos lugares onde essas memórias são produzidas: não mais apenas nos museus ou academias — lugares de construção do conhecimento institucional. Mas, diante da difusão da sociedade de massas e da emergência de novos atores político-sociais, na imprensa, na televisão, na publicidade, além de outras organizaçóes políticas como sindicatos, movimentos populares, estudantis etc. Em todos esses novos espaços discursivos, cada memória produzida ali representa as aspiraçóes de um grupo específico no processo de reafirmação (e muitas vezes, de construção mesma) de suas identidades individuais e coletivas, ${ }^{27}$ antes subjugadas na totalidade desigual do Estado. Esses discursos de memória assumem também uma posiçấo de contraponto ao conhecimento institucional produzido pelos órgãos oficiais do Estado, na tentativa de harmonizar as desigualdades da sociedade através da unificação totalizante que o conceito de "nação" representa.

A "história oficial" erigida pelo franquismo tomou a forma de um projeto institucional de construção de uma memória oficial, através da censura e da repressão, e de maneira mais efetiva através da educação formal de crianças e jovens, com livros didáticos onde apenas a versão oficial existia. A ideologização do sistema educacional espanhol durou até a metade dos anos 1990, quando os efeitos da mitologização do passado ainda eram sentidos na educação básica e secundária espanhola. Os livros didáticos foram fundamentais para instrumentalizar o imaginário infantil, principalmente nos primeiros vinte anos do regime franquista, construindo um discurso monológico onde a versão oficial da história era a única permitida. ${ }^{28} \mathrm{O}$ efeito disso foi o que o historiador espanhol Angel Viñas chamou de uma geração de escritores que, mais do que acreditar nos mitos franquistas, construíram seu discurso político sobre eles. ${ }^{29}$

Eventos como a Guerra Civil espanhola, cuja memória fora uma das mais extirpadas durante o regime, para assumir a condição de "evento fundador" do Estado franquista, detêm,

\footnotetext{
${ }^{26} \mathrm{O}$ que se identifica, como a historiografia do século XX vem relatando, por exemplo, nas teses de Nora, são as multiplicidades narrativas que compóem as relaçôes sociais no espaço público - a multiplicidade de temporalidades e ritos privados, que atuam e se conflitam na sociedade. Tensôes que são, contudo, ao mesmo tempo, tấo bem captadas quanto "amenizadas" pelos mecanismos institucionais que confeccionam os discursos da história oficial, as narrativas da memória coletiva e da identidade coletiva, calcadas na valorização da nacionalidade, do patriotismo e da coletividade. Para esse debate, ver também FERRO, Marc. $A$ história vigiada. São Paulo: Martins Fontes, 1989.

${ }^{27}$ Tal qual argumenta Michael Pollak. Memória e identidade social. Estudos históricos, v. 5, n. 10, 1992.

${ }^{28}$ CAPELATO, Maria Helena. Ensino primário franquista: os livros escolares como instrumento de doutrinação infantil. Revista Brasileira de História, São Paulo, v. 29. n. 57, jan./jun., 2009, p. 117-145.

${ }^{29}$ VIÑAS, Angel. La conspiración del General Franco y otras revelaciones de uma Guerra civil desfigurada. Barcelona: Critica, 2011.
} 
até hoje, papel fundamental nesse processo. Antes do acesso aos arquivos oficiais (estrangeiros e locais), grande parte da história da guerra apenas pôde ser recuperada — graças ao longo processo de censura - através do relato dos muitos participantes que ali se engajaram, vindos de toda parte do mundo, para a luta contra o fascismo. Essas "testemunhas oculares" puderam não apenas presenciar os inúmeros eventos e controvérsias que cercaram a derrota da Frente Popular, como também puderam transmiti-los, através de suas memórias pessoais, para as geraçôes futuras, construindo assim um contraponto ao discurso oficial do Estado.

Esses relatos, inclusive pela dissonância que carregam entre si, puderam, ao mesmo tempo, manter viva a memória da República em sua luta contra os rebeldes quando lançados à época. Como, depois da derrota da República, em 1939, se constituíram como uma rica fonte para o processo de (re)construção da memória da Guerra, soterrada em meio a história oficial, anos mais tarde. Entendemos então que é nessa perspectiva que os livros editados pelo Left Book Club que trataram da Guerra Civil espanhola podem ser interpretados como importante fonte historiográfica.

Dos 255 títulos lançados sob o selo do Clube ao longo de seus 13 anos de funcionamento, é possível dizer que praticamente todos aqueles publicados na segunda metade da década de 1930 tiveram influência direta da Guerra Civil espanhola. Treze deles, contudo, foram dedicados diretamente ao tema da Guerra. Esses livros são listados na tabela a seguir.

Tabela 1: Lista de livros publicados pelo LBC tendo a Guerra Civil espanhola como tema:

\begin{tabular}{|c|c|c|}
\hline Autor & Título do livro & Mês/Ano da publicaçáo \\
\hline Harry Gannes/Theodore Repard & Spain in Revolt & Dezembro de 1936 \\
\hline Otto Katz & The Nazi Conspiracy in Spain & Janeiro de 1937 \\
\hline Geoffrey Cox & Defense of Madrid & Março de 1937 \\
\hline Hewlett Johnson & $\begin{array}{l}\text { Report of a Religious } \\
\text { Delegation to Spain }\end{array}$ & Maio de 1937 \\
\hline $\begin{array}{l}\text { Robert Donnington/Barbara } \\
\text { Donnington }\end{array}$ & The Citizens Faces War & Maio de 1937 \\
\hline S. Erckner & $\begin{array}{c}\text { Hitler's Conspiracy Against } \\
\text { Peace }\end{array}$ & Junho de 1937 \\
\hline G. D. H. Cole & The People's Front & Julho de 1937 \\
\hline Hubertus Lowenstein & A Catholic in Republican Spain & Novembro de 1937 \\
\hline Arthur Koestler & Spanish Testament & Dezembro de 1937 \\
\hline Frank Jellinek & The Civil War in Spain & Junho de 1938 \\
\hline H. R. G. Greaves/David Thomson & The Truth about Spain & Setembro de 1938 \\
\hline Thomas Jefferson Hamilton & $\begin{array}{c}\text { Appeasement's Child: the Franco } \\
\text { Regime in Spain }\end{array}$ & Julho de 1943 \\
\hline Isabel “de Palencia” Oyarzábal & $\begin{array}{l}\text { Smouderling freedom: the Story } \\
\text { of the Spanish } \\
\text { Republicans in Exile }\end{array}$ & Novembro de 1946 \\
\hline
\end{tabular}

Tabela baseada no catálogo da coleçáo The Left Book Collection, pertencente à Special Collection \& Library Archives, 1936-1948, University of Sheffield, Reino Unido. Disponível em: <http://www.shef.ac.uk/library/ special/leftbook.pdf>. 
A percepção britânica sobre a Guerra Civil na Espanha mudou no outono de 1936. A ideia de um conflito isolado, produzido pelas incongruências internas espanholas, deu lugar a imagem do preâmbulo de um conflito moderno de proporçôes internacionais. É importante ter em conta então que o LBC publicou um dos primeiros trabalhos a relatar a guerra na Espanha em primeira mão, ajudando a chamar a atenção internacional para o conflito: Spain in Revolt, de Harry Gannes e Theodore Repard, publicado em dezembro de 1936.

Outro tema que ajudou a ecoar internacionalmente o conflito espanhol foi o bombardeio da vila basca de Guernica, em 26 de abril de 1937, pela Legião Condor, formada por aviôes da Luftwaffe. Na Grã-Bretanha, com uma opinião pública chocada pelos relatos dos jornalistas sobre as mortes massivas, incluindo crianças, as pressôes por uma tomada de posição do governo local cresceram sem, contudo, afetar diretamente as posiçôes diplomáticas na guerra, mesmo que muitas oportunidades tivessem sido dadas para que Baldwin decidisse por intervir na Espanha contra os nacionalistas. Entre elas, o ataque "pirata" de submarinos italianos a serviço dos nacionalistas a navios ingleses, no verão de 1937, e o bombardeio a navios do país em portos republicanos no verão de 1938. Açóes contornadas pela diplomacia parcialista do Foreing Office. As pressóes da opinião pública sobre a guerra na Espanha, contudo, foram suficientes a ponto de o governo britânico gastar a soma de $£ 73$ mil entre os anos de 1936 e 1937, apenas com a evacuação de refugiados do País Basco, contrariando uma política de isolamento que datava da Primeira Guerra Mundial. ${ }^{30}$

Sobre efeitos dos bombardeios às cidades bascas na opinião pública britânica, Tom Buchanan emenda: "British opinion, arleady in a subdued panic due to the fear of mass destruction from the air, now for the first time witnessed the reality in terms easily transferable to British towns." "31 Não à toa, o LBC publica alguns trabalhos focados nas preparaçôes da população civil a ataques aéreos — as chamadas "Air Raid Precautions" (A.R.P, na sigla em inglês), que se tornariam tema central na opinião pública britânica depois da entrada do país na Segunda Guerra Mundial. A primeira circular sobre as preparaçôes da população civil contra ataques aéreos surge em 1935. Em 1937, o governo Baldwin cria a Air Raid Wardens' Service, que no primeiro ano recrutou 200 mil voluntários. O movimento "ARP” ganhou repercussão nacional, no entanto, sob os trabalhos dos comunistas, capitaneado pelo biólogo J. B. S. Haldane, membro do movimento Social Relations in Science (SRS), ligado ao CPGB, e baseado em suas experiências como médico voluntário na Guerra Civil espanhola. A partir de 1938, Haldane passa a coordenar o movimento pelos comunistas, buscando ações efetivas para preparar a população britânica contra os bombardeios aéreos numa possível guerra vindoura. Com Haldane à frente, o movimento produziu um manual coletivo, intitulado "The protection of the public from aerial attack", publicado pelo LBC em fevereiro de 1937. O bió-

\footnotetext{
${ }^{30}$ BUCHANAN, Tom. Edge of darkness: British "front-line" diplomacy in the Spanish Civil War, 19371938. Contemporary European History, v. 12, n. 3, 2003.

${ }^{31}$ BUCHANAN, Tom. Britain and the Spanish Civil War, op. cit., p. 29.
} 
logo lançou ainda outros dois outros trabalhos sobre o mesmo tema, ambos publicados pelo LBC: "A.R.P”, em setembro de 1938; e "How to be safe from the Air Raids", publicado em novembro do mesmo ano. Contrariando os projetos comissionados de abrigos individuais do governo britânico (como as "Anderson shelters"), por exemplo, as campanhas populares lideradas pelos comunistas conseguiram a transformação das estações de metrô de Londres em abrigos subterrâneos para a populaçáo civil, o que salvaria milhares de vidas durante a Segunda Guerra Mundial.

Figura 1: Spain in Revolt, de Harry Gannes e Theodore Repard, publicado em dezembro de 1936. O primeiro livro sobre a Guerra Civil espanhola publicado pelo LBC.

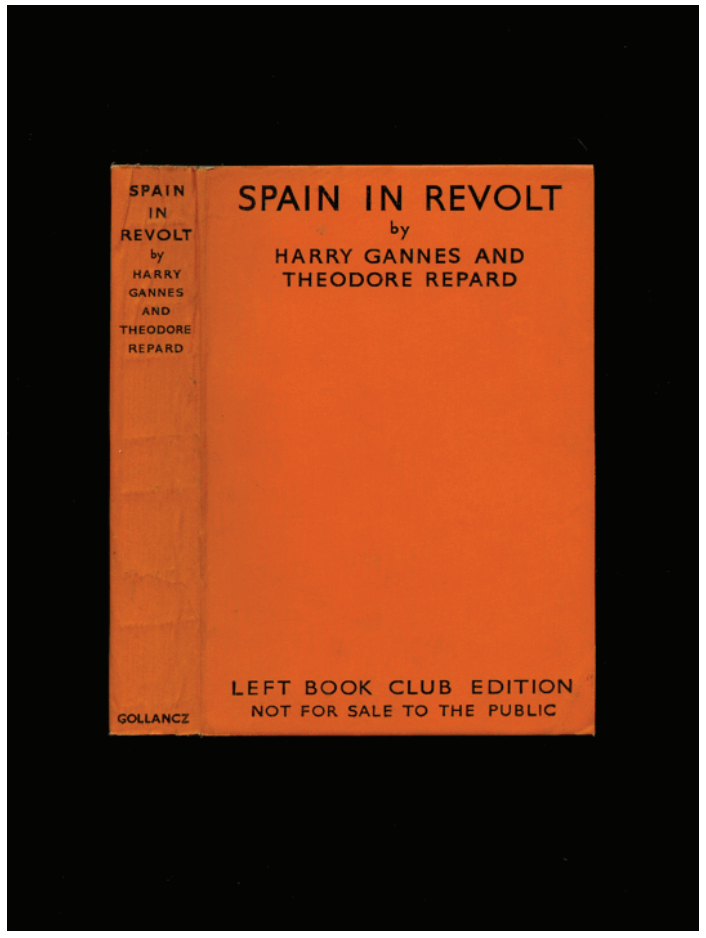

Fonte: Left Book Club Collection — University of Sheffield, Sheffield, Reino Unido. Catálogo disponível em: <http://www.shef.ac.uk/library/special/leftbook>.

Pela primeira vez desde 1918, um novo conflito internacional parecia bater às portas dos cidadãos britânicos. A imagem do povo basco, democrático e sufocado pelos dois lados em conflito, construída pelo correspondente do The Times à época, George Lowther Steer, pareceu cativar os leitores britânicos, reforçando um sentimento humanitário, ao mesmo tempo que os novos avanços tecnológicos de uma nova guerra internacional - bombardeios de cidades indefesas, ataque a civis, movimentos de migração de crianças e mulheres refugiadas etc. - despertavam o medo. 
No ano de 1937, aliás, o LBC publicou um total de oito livros sobre a Guerra Civil espanhola - média de quase um por mês. Mesmo ano que marca o ápice da mobilização para a ajuda dos republicanos entre a esquerda britânica. Em janeiro, fora lançada a Unity Campaign, como estratégia da esquerda para o auxílio na Guerra Civil. Os comunistas se uniram ao pequeno Independent Labour Party (ILP) e à Socialist League (facção do Labour Party). Em março de 1937, em meio a essa tentativa de construir a Frente Única em solo britânico tendo a defesa da República espanhola como leitmotiv, foi publicado pelo LBC o livro Defense of Madrid, de Geoffrey Cox — que cobriu o desencadeamento dos primeiros meses da guerra para o jornal News Chronicle, de Londres.

O ILP fora criado em 1893 e foi por muitos anos o principal componente político do Labour Party. Em 1918, é criada uma constituição própria para os membros do Labour Party. Junto com o fracasso do governo trabalhista nos anos de 1920, começaria a provocar uma cisão que resultaria na desfiliação do ILP em 1932, quando se torna um partido independente autodeclarado como socialista revolucionário. Ao longo da primeira metade da década de 1930, sua popularidade cai, apesar de grande representatividade em grandes cidades como Glasgow. Em 1932, contava com 16 mil membros, para, em 1935, esse número cair para 4.392 filiados. ${ }^{32}$

Figura 2 (à esquerda): frontispício do livro A. R. P., de J. B. S. Haldane, publicado pelo LBC em setembro de 1938, anunciando mais uma campanha de arrecadaçáo de dinheiro para ajuda humanitária das vítimas da Guerra Civil espanhola. Figura 3 (à direita): capa da edição do LBC do livro de Haldane.
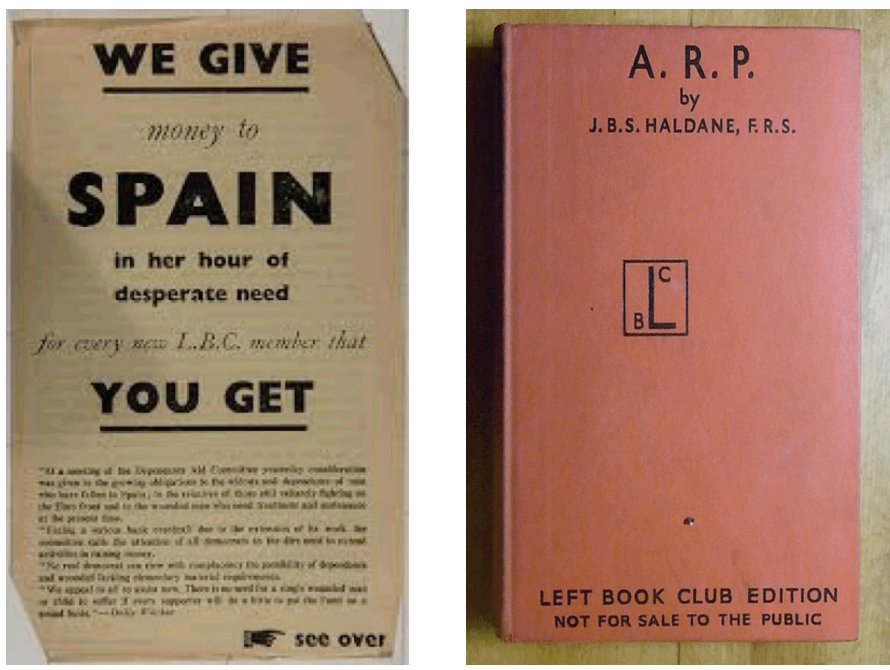

Fonte: Left Book Club Collection — University of Sheffield, Sheffield, Reino Unido. Catálogo disponível em: <http://www.shef.ac.uk/library/special/leftbook>.

\footnotetext{
${ }^{32}$ BUCHANAN, Tom. The Death of Bob Smillie, the Spanish Civil War, and the Eclipse of the Independent Labour Party. The Historical Journal, v. 40, n. 2, p. 435, jun. 1997. Disponível em: <http://www.jstor.org/ stable/2640074>. Acesso em: 12 abr. 2008.
} 
$\mathrm{Na}$ Espanha, o ILP tinha contato apenas com o POUM, criado em 1935. Criara inclusive um fundo de assistência próprio, separado do fundo de assistência mantido pelo Labour Party. Em maio de 1937, o ILP arrecadou um total de $£ 2.272$, das quais $£ 1.022$ foram enviadas para a Espanha. O restante do dinheiro fora usado para a compra de suprimentos médicos e ambulâncias, que representou o contingente militar do partido a ser enviado para a Espanha. Além dessas medidas, ótimas para promover o próprio partido na cena política britânica, o ILP organizou um abrigo para crianças bascas refugiadas em Somerset, administrado com fundos próprios..$^{33} \mathrm{O}$ papel das Frentes Populares formadas em defesa do governo republicano, cuja inspiração seria o Front Populaire, formado na França, no governo de Leon Blum, seria o tema do livro do historiador G. D. H. Cole, The People's Front, lançado pelo LBC em julho de 1937.

Alguns dos livros publicados pelo LBC na metade de 1937 refletiam tanto a situação humanitária em meio a Guerra Civil quanto a situação da população católica em meio à guerra "anticlerical" das milícias anarquistas, largamente explorada pela imprensa internacional conservadora e de direita para forçar a opinião pública contra as forças republicanas. Ambos os temas pareciam centrais para serem explorados na guerra de narrativas construídas ao longo dos anos do conflito a fim de mobilizar as audiências simpáticas a um ou ao outro dos lados envolvidos. Esse foi o caso do livro Report of a Religious Delegation to Spain, de Hewlett Johnson, publicado em maio de 1937. Já em novembro do mesmo ano, o LBC publicou o livro A Catholic in Republican Spain, de Hubertus Lowenstein.

Figura 4: Defense of Madrid, de Geoffrey Cox, lançado pelo LBC em março de 1937. Aqui em capa da editora Victor Gollancz Ltd.

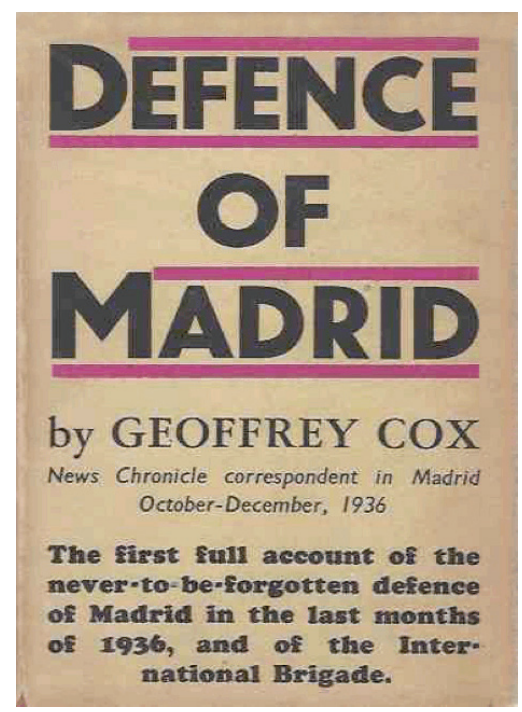

Fonte: Left Book Club Collection — University of Sheffield, Sheffield, Reino Unido. Catálogo disponível em: <http://www.shef.ac.uk/library/special/leftbook>.

33 Ibidem, p. 439. 
Maio de 1937 é o momento de uma mudança pivotal das relaçôes da opinião pública britânica com o conflito espanhol. Naquele mês, 4 mil crianças refugiadas bascas desembarcam na Inglaterra. Segundo Buchanan, a presença das crianças sensibilizou a opinião pública britânica a um ponto até então não alcançados por qualquer outra campanha de arrecadação de ajuda para a Guerra Civil. Foi também o único momento em que as opiniôes contrárias das várias organizaçóes de ajuda humanitária pareceram confluir na mesma direção. ${ }^{34} \mathrm{O}$ livro The citizens faces war, de Robert Donnington e Barbara Donnington, lançado pelo LBC naquele mês, aborda justamente os efeitos da guerra trazida às populaçóes civis espanholas.

O momento de evacuação das crianças coincidiu com a ofensiva nacionalista sobre o País Basco, em abril de 1937, quando as forças rebeldes, apoiadas pelos bombardeios da Luftwaffe nazista, destruíram a capital Bilbao e outras cidades menores, como Guernica. Antes da Inglaterra muitas crianças já haviam sido evacuadas para a França. Dois livros publicados pelo LBC também em 1937 se ocupavam da atuação dos nazistas em apoio aos nacionalistas espanhóis: The Nazi Conspiracy in Spain, de Otto Katz, publicado em janeiro de 1937; e Hitler's Conspiracy Against Peace, de S. Erckner, de junho. Ambos serviram para apresentar ao público a hipocrisia dos governos britânico e francês, que insistiam publicamente em uma política de neutralidade em relação ao conflito, diante do apoio aberto de nazistas e italianos ${ }^{35}$ aos nacionalistas, enquanto os soviéticos apoiavam os republicanos. ${ }^{36}$

O LBC publicou muitos outros livros que já apresentavam os perigos do nazismo para a Europa ocidental antes mesmo da eclosão da Segunda Guerra Mundial, em 1939. Esse foi o caso do livro do imigrado alemão em Londres, Rudolf Oldem, Hitler the Pawn, publicado pelo clube em junho de 1936, que analisava a ascensão de Hitler à chancelaria de seu país e o movimento de massa que o acompanhava. O nazismo foi tema também do romance de An-

\footnotetext{
${ }^{34}$ BUCHANAN, Tom. Britain and the Spanish Civil War, op. cit., p. 109.

${ }^{35}$ Assim como Hitler, ao enviar a Legiáo Condor, Mussolini apoiou abertamente os nacionalistas, com envio de força militar massiva para a Espanha. Os fascistas italianos se organizaram no Corpo di Truppo Volontarie (CTV), uma brigada motorizada enviada à Espanha em 15 de dezembro de 1936, e integrada a Tercio de Estranjeros, a Legião Estrangeira Espanhola, composta por soldados de outras nacionalidades. A CTV contou com cerca de 50 mil soldados. Ver SCHWARTZ, Fernando. La internacionalización de la Guerra Civil Española. Barcelona: Planeta, 1999; NADAL, Luis Urteaga Francesc; MURO, José Ignacio. La cartografia del Corpo di Truppe Volontarie, 1937-1939. Hispania, v. LXII/1, n. 210, 2002, p. 283-298. Disponível em: <http://hispania.revistas.csic.es/index.php/hispania/article/viewFile/273/275>.

${ }^{36}$ Quanto ao apoio dos soviéticos, desde julho de 1936 Stalin declarou apenas simpatia pela Terceira República espanhola. Em termos de apoio efetivo, com suporte militar, envio de mantimentos e armas, o apoio soviético foi tardio, ocorrendo apenas a partir de outubro de 1936, por pressão do Comintern e outros PCs internacionais, como o francês e o CPGB. Ainda sim, como mostra Schwartz, os soviéticos relutaram em apoiar abertamente os republicanos - por exemplo, com o envio de tropas - , pois haviam integrado o Comitê de Não Intervençáo internacional, reunido pela primeira vez em Londres, em 9 de setembro de 1936, e que definiu, através da assinatura conjunta de 27 nações do Pacto de Não Intervenção, que outros países não interviriam diretamente no conflito espanhol. SCHWARTZ, Fernando. La internacionalización de la Guerra Civil Española, op. cit.
} 
dré Malraux, Days of Contempt, publicado pelo LBC em agosto de 1936, o mesmo Malraux que, adiante, se juntaria à resistência republicana na Espanha. Já o livro de Jan Petersen, Our Street, publicado pelo LBC em fevereiro de 1938, narrava a resistência da militância comunista na Alemanha aos nazistas. Outro livro cujo foco foi a ascensão nazista e seus perigos foi War Against the West, de Aurel Kolnai, publicado pelo LBC em julho de 1938.

Ainda sobre a temática dos refugiados espanhóis, Gollancz teve papel ainda mais decisivo quando empregou o aparato do LBC nas várias campanhas populares promovidas por vários setores da esquerda britânica para arrecadação de fundos a fim de bancar o envio de ajuda humanitária às vítimas da guerra. Campanhas que ajudaram na criação da Spanish Medical Aid Committee, em agosto de 1936 e do National Joint Committee for Spanish Relief, em novembro daquele ano. $\mathrm{O}$ apoio de Gollancz e a estrutura do LBC foram decisivos ainda para a campanha de acolhimento dos órfãos bascos na Grã-Bretanha. A evacuação para a Inglaterra foi resultado da campanha encabeçada por Leah Manning, então agente do National Joint Committee em Bilbao. ${ }^{37}$

A campanha de unificação das esquerdas em solo britânico, no entanto, não durou muito. O Labour Party forçou a saída da Socialist League. Na Espanha, comunistas e o ILP não se entendiam, já que os últimos apoiavam o POUM e a ideia de atrelar a luta contra o fascismo à revolução, enquanto os comunistas enxergavam a guerra como uma etapa para a manutenção da democracia e da constitucionalidade do Estado espanhol contra a defesa do arcaísmo e do feudalismo das velhas instituiçôes pelos nacionalistas. As animosidades aumentam quando Moscou passa a acusar os trotskistas de traidores e colaboradores dos nacionalistas. Em junho de 1937, o POUM é suprimido e seus membros declarados inimigos da causa republicana pelos comunistas. O ILP então rompe relaçôes com os comunistas em Londres, pondo fim à ideia de uma união da esquerda britânica em favor da República espanhola.

Para os comunistas britânicos, a Guerra Civil espanhola representou uma etapa para a consolidação de sua estrutura organizativa e permitiu a ampliação de suas ramificaçôes por todas as grandes cidades industriais britânicas através dos vários comitês criados para auxílio às vítimas da guerra. Para o ILP, ao contrário, a guerra na Espanha representou seu declínio. Tom Buchanan afirma que a única contribuição relevante do ILP para a política britânica foi estar no olho do furacáo quando irrompeu a luta entre os comunistas e sua oposição anti-stalinista. E muito disso se deve à George Orwell e toda sua produçáo acerca da guerra publicada nos jornais britânicos da época, tanto quanto seu livro Homage to Catalonia, um dos melhores publicados à época sobre a guerra. ${ }^{38}$

As mudanças das relaçóes entre os grupos da esquerda dentro da Espanha repercutiram também no teor das publicaçôes do LBC. Em dezembro de 1937, o clube publica o último

\footnotetext{
${ }^{37}$ BUCHANAN, Tom. Britain and the Spanish Civil War, op. cit., p. 109-110.

${ }^{38}$ BUCHANAN, Tom. The Death of Bob Smillie, the Spanish Civil War, and the Eclipse of the Independent Labour Party, op. cit.
} 
livro daquele ano dedicado à Guerra Civil: Spanish Testament, de Arthur Koestler. Este seria um dos primeiros a denunciar o autoritarismo dos soviéticos do lado republicano e suas táticas de intimidação e sabotagem das outras forças que compunham a resistência ao fascismo na Espanha. Ao largo do ano de 1938, o LBC publicaria outros livros cujas denúncias da atuação autoritária dos comunistas dentro da frente republicana seriam desnudadas. Esse foi o caso do The Civil War in Spain, de Frank Jellinek, publicado em junho de 1938, e o livro The Truth about Spain, de H. R. G. Greaves e David Thomson, publicado em setembro do mesmo ano.

Paralelamente, Gollancz tentava apaziguar as críticas aos comunistas publicadas por membros do LBC, como Jellinek e Orwell. A crítica de Orwell contra a atuação soviética na Espanha fez Gollancz recusar a publicação de um dos livros que mais chamaria a atenção sobre a Guerra Civil entre aquela geração: justamente seu Homage to Catalonia.

Gollancz foi o primeiro editor de Orwell na Inglaterra, publicando seis dos sete livros do autor lançados na década de 1930, cinco deles por sua editora privada, a Victor Gollancz Ltd. ${ }^{39}$ Pelo LBC, Orwell publicou apenas um livro e também o primeiro de não ficção da carreira: o The Road to Wigan Pier, uma reportagem encomendada pelo LBC a fim de apresentar as condiçóes de vida dos mineiros da região norte da Inglaterra em plena crise da década de 1930. O livro apareceria sob o selo do LBC, como escolha do mês, em março de 1937. De fato, o The Road to Wigan Pier foi o livro que mais sucesso obteve entre as escolhas especiais do clube lançadas mês a mês aos assinantes, vendendo 43 mil cópias, e dando a Orwell, pela primeira vez, grande notoriedade. Orwell dividiu aquele trabalho em duas partes. A primeira tratava das condiçôes de vida das famílias de trabalhadores mineiros de Yorkshire e Lancashire. Na segunda, criticou duramente as classes intelectuais da esquerda britânica e aquilo que considerava como um descolamento das classes operárias, críticas que geraram controvérsias e desacordos entre os editores do LBC. Como solução, Gollancz prefaciou a ediçấo do livro a ser lançada pelo clube, respondendo alguns dos questionamentos de Orwell.

À época da publicação do The Road to Wigan Pier em Londres, Orwell já se encontrava na Espanha, filiado ao POUM, combatendo na frente de Aragón e enviando textos para imprensa britânica. O primeiro deles, aliás, é publicado ainda em 1937: "Spilling the Spanish Beans", pelo jornal New English Weekly, publicado em duas partes, nos dias 29 de junho e 2 de setembro de 1937. Da Espanha, Orwell escreveu a Gollancz, em 1o de maio de 1937, agradecendo o prefácio ao The Road to Wigan Pier pela possibilidade do debate que ele gerou e anunciando a ideia para um novo livro, dedicado a apresentar tudo aquilo que ele tinha visto até então na Espanha (esse livro seria o Homage to Catalonia). ${ }^{40}$

\footnotetext{
${ }^{39}$ Orwell publicou na década de 1930, sob o selo da Victor Gollancz Ltd., os seguintes livros: Down and Out in Paris and London (1933), Burnese Days (1935), Clergyman's Daughter (1935), Keep the Aspidistra Flying (1936) e Coming Up for Air (1939). Além disso, publicou a coleção de ensaios Inside the Whale (1940).

${ }^{40}$ Carta de Orwell para Gollancz. 1ำ de maio de 1937. In: ORWELL, George. Orwell in Spain. Londres: Penguin Books, 2001, p. 17.
} 
É interessante notar que grande parte das críticas de Gollancz a Orwell surgem então em um momento de extrema polarização da esquerda internacional em meio ao racha da frente republicana na Espanha, quando, desde maio, anarquistas e trotskistas haviam sido excomungados como "quinta coluna" pelos comunistas, e seus militantes estavam sendo perseguidos e encarcerados nas chamadas "chekas". ${ }^{41}$ Por isso, as denúncias quanto ao racha da Frente Popular espanhola não foram isoladas na obra de Orwell. Ao contrário, elas pulularam em vários outros livros e artigos que circularam na imprensa britânica da época, denunciando as açôes repressivas dos comunistas ante outros grupos como o POUM. Outro exemplo dessa crítica é o livro de Franz Borkenau, The Spanish Cockpit (1937), que Orwell resenha para o jornal Time and Tide, de 31 de Julho de 1937, ${ }^{42}$ considerado um dos livros mais lúcidos sobre a atuação anarquista durante a Guerra na Espanha lançado à época. Para Gollancz, aquela não era a hora de, assim como ocorria na Espanha, forçar uma cisão dentro do Popular Front britânico. E as duras opiniōes de Orwell, tanto no The Road to Wigan Pier quanto em seus primeiros textos que já circulavam sobre a situação na Espanha, forçavam essa polarização.

Mais crítico ainda aos comunistas seria o Homage to Catalonia. Finalizado na França pouco tempo depois de Orwell escapar da GPU, em solo espanhol, junto com sua primeira esposa, num trem entre Barcelona e Paris, em 23 de junho de 1937, o livro expunha a cisão da Frente Popular espanhola, a perseguição dos anarquistas e do POUM pelas Brigadas Internacionais e as políticas autoritárias do Comintern, que, segundo sua visão, ajudavam a erodir a defesa da República espanhola.

Orwell produziu uma série considerável de artigos, ensaios, resenhas e revisóes, sobre o conflito, logo após sua fuga para a França em 1937. Na maioria desses textos, publicados em jornais e revistas da Inglaterra, Estados Unidos e França, o foco maior de suas críticas foi aquilo que ele identificou ser o processo de supressão da dissidência comunista na Frente Popular: a perseguição sumária de anarquistas e de todos os outros partidos que não seguiam as determinaçóes soviéticas, através da liderança das Brigadas Internacionais à frente do governo republicano. E, mais ainda, toda a campanha de difamação dessa dissidência nos jornais comunistas pelo mundo.

Para Orwell, ficou muito claro, como sua produção crítica atesta, que tais disputas não apenas minaram as forças de resistência contra Franco, já debilitadas pela falta de apoio de outros países, em detrimento do apoio alemão e italiano ao exército falangista. Mais ain-

\footnotetext{
${ }^{41}$ As chekas eram instalaçóes organizadas na zona republicana durante a Guerra Civil espanhola, com a funçáo de deter, interrogar, torturar, julgar de forma sumária e executar todos aqueles acusados de colaborar com os nacionalistas. Diversos grupos que integravam as Frentes Populares, entre eles as Brigadas Internacionais, tinham suas chekas, que eram nominadas, geralmente, pelo nome da rua que a abrigavam ou da pessoa que a dirigia. Algumas delas tiveram apoio institucional do governo. A maioria, contudo, era mantida pelo grupo que a utilizava. Ver THOMAS, Hugh. A Guerra Civil espanhola. Rio de Janeiro: Civilização Brasileira, 1964. 2 v.

${ }^{42}$ ORWELL, George. Orwell in Spain, op. cit., p. 229-31.
} 
da, a ação de repressão contra anarquistas principalmente, e sua identificação com o que a propaganda comunista intitulava de forças "trotskistas", empreendia um processo de manipulação da própria história da guerra. Através do discurso oficial soviético, apresentado, principalmente em seus veículos de informação oficiais, Orwell pode identificar uma ação de mão-dupla: por um lado, a desqualificação das açôes dessa dissidência, tanto quanto de seus agentes; por outro, a legitimação das açóes comunistas. Essa dupla-ação resultante da propaganda oficial soviética corroborou com a construção da imagem das brigadas comunistas como única força capaz (ideológica e militarmente) de confrontar a ascensão fascista na Espanha. Processo que, por exemplo, influenciou diretamente na escritura da história da Guerra Civil, já que desconsiderou por muito tempo o papel fundamental que as milícias anarquistas detiveram em várias regióes da Espanha, principalmente nos primeiros meses após o início da Guerra Civil, à frente das forças de defesa do governo republicano.

Para Orwell ainda, como ele escreveria em seu último ensaio crítico sobre a Guerra Civil, "Looking Back on the Spanish War", publicado em 1942, as disputas entre comunistas e sua dissidência influenciariam decisivamente na própria escritura da história da guerra, quase que numa antevisão das ações de repressão engendradas pela ditadura franquista nos anos posteriores:

Lembro-me de ter dito uma vez a Arthur Koestler, "A história parou em 1936", na qual ele acenou com a cabeça em concordância imediata. Ambos estávamos pensando no totalitarismo em geral, mas mais particularmente na Guerra Civil espanhola. No começo da vida, notei que nenhum evento fora relatado corretamente por um jornal, mas na Espanha, pela primeira vez, vi relatórios de jornais que náo tinham qualquer relaçáo com os fatos, nem mesmo a relação que está implícita em uma mentira comum. Eu vi grandes batalhas relatadas onde não houve lutas e silêncio completo onde centenas de homens foram mortos. Eu vi tropas que lutaram bravamente denunciadas como covardes e traidores, e outros que nunca viram um tiro disparado serem saudadas como heróis de vitórias imaginárias; e vi jornais em Londres vendendo essas mentiras e intelectuais ansiosos construindo superestruturas emocionais sobre eventos que nunca aconteceram. Eu vi, de fato, a história escrita não em termos do que aconteceu, mas do que deveria ter acontecido de acordo com várias "linhas partidárias". [tradução do autor $]^{43}$

\footnotetext{
${ }^{43}$ I remember saying once to Arthur Koestler, "History stooped in 1936", at which he nodded in immediated understanding. We are both thinking of totalitarianism in general, but more particularly of the Spanish civil war. Early in life I had noticed that no event is ever correctly reported in a newspaper, but in Spain, for the first time, I saw newspaper reports which did not bear any relation to the facts, not even the relationship which is implied in the ordinary lie. I saw great battles reported where there been no fighting, and complete silence where hundreds of men had been killed. I saw troops who had fought bravely denounced as cowards and traitors, and others who had never seen a shot fired hailed as the heroes of a imaginary victories; and I saw newspapers in London retailing these lies and eager intellectuals building emotional superestructures over events that had never happened. I saw, in fact, history being written not in terms of what happened but of what ought to have happened according to various "party lines". (ORWELL, 2001, p. 351-352)
} 
O manuscrito do Homage to Catalonia nem havia chegado às mãos de Gollancz, que o recusa em carta a Orwell datada de 5 de julho de 1937, afirmando ser incapaz de publicar um ataque aos comunistas àquele ponto da guerra. Apesar de um contrato em vigência, Orwell consegue negociar uma liberaçáo para apresentar o livro a outra editora, enviando o manuscrito a Martin Secker, que se interessa. O livro seria publicado, por fim, em 25 de abril de 1938, com tiragem inicial de 1.500 cópias pela editora Secker \& Warburg, em Londres. ${ }^{44}$

Figura 5 (à esquerda): Spanish Testament, de Arhutr Koestler, publicado em dezembro de 1937. Figura 6 (à direita): The civil War in Spain, de Frank Jellinek, publicado em junho de 1938.
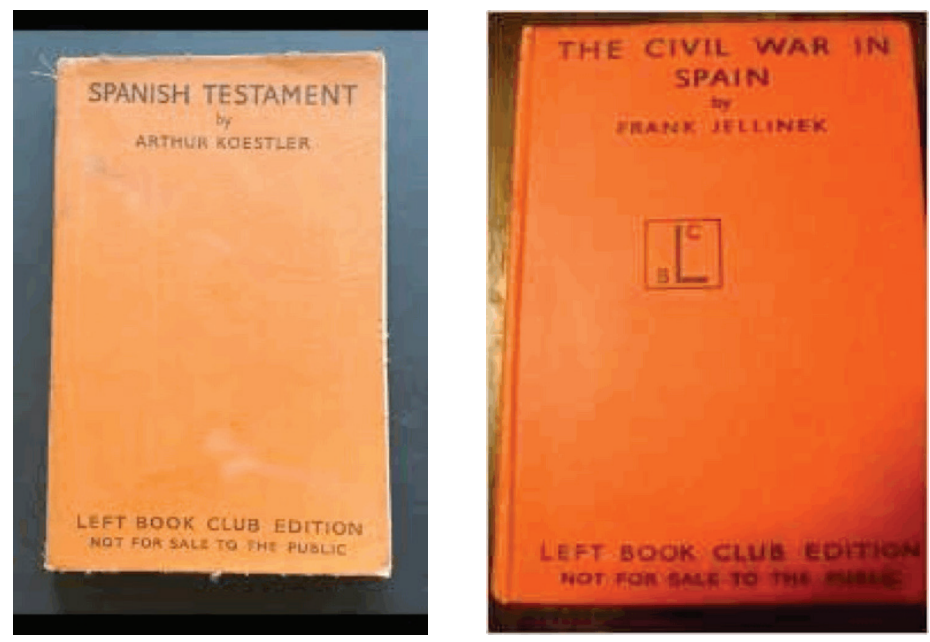

Fonte: Left Book Club Collection — University of Sheffield, Sheffield, Reino Unido. Catálogo disponível em: <http://www.shef.ac.uk/library/special/leftbook>.

No mesmo período em que a Frente Popular espanhola havia rachado e os nacionalistas avançavam, Gollancz continuava empregando todo o aparato do LBC em prol da resistência republicana. E a revista Left News foi também um espaço utilizado para organizar o apoio aos republicanos, com dois números dedicados exclusivamente à Guerra Civil: um em dezembro de 1937 e outro em janeiro de 1938.

No editorial assinado por Victor Gollancz, publicado na edição de janeiro de 1938, pode-se ler claramente um chamado à opinião pública britânica para a defesa da causa republicana espanhola. Segundo Gollancz, a Guerra Civil na Espanha era o principal conflito desencadeado na Europa no período do pós-Primeira Guerra Mundial, simbolizando, ao mesmo tempo, a ascensão definitiva do fascismo pelo continente e os ecos de resistência das pessoas comuns. Madri, aliás, nas palavras de Gollancz, era o bastiáo de defesa da "civilização" contra a barbárie fascista, já que outras partes da Europa, como a Alemanha, a Itália e a Áustria, haviam cedido à sedução fascista sem mostrar uma resistência massiva.

\footnotetext{
${ }_{44}^{4}$ Todas as informaçôes relativas a publicação do Homage to Catalonia estão no Orwell in Spain, op. cit., p. 27.
} 
Figura 7: Homage to Catalonia, primeira ediçáo publicada em Londres, 25 de abril de 1938, pela editora Secker \& Warburg. Livro recusado por Victor Gollancz por conta das críticas de Orwell à atuaçáo comunista na Guerra Civil Espanhola.

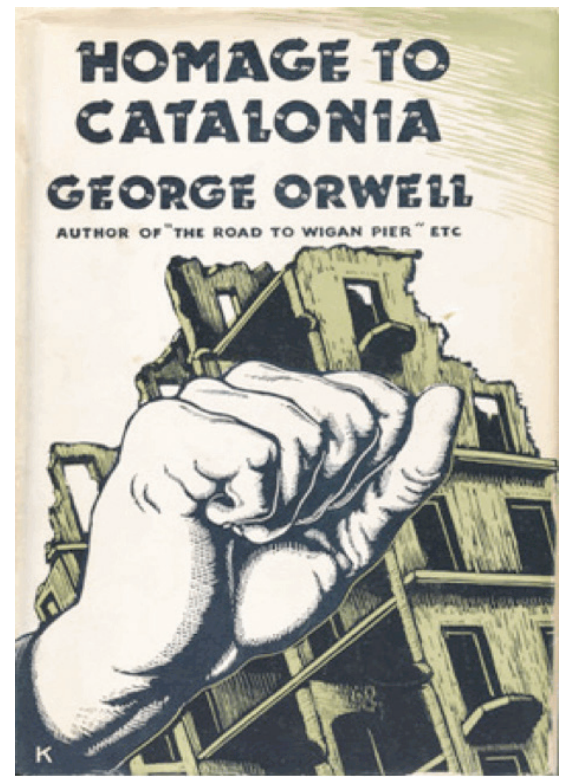

Fonte: Left Book Club Collection — University of Sheffield, Sheffield, Reino Unido. Catálogo disponível em: <http://www.shef.ac.uk/library/special/leftbook>.

Enquanto isso, a capital espanhola permanecia de pé na luta contra os nacionalistas, apoiados por Hitler e Mussolini. Gollancz chama a atenção para a grave situação humanitária vivida por trás da frente republicana, que atingia especialmente as crianças, as principais vítimas dos bloqueios de alimentos e medicamentos impostos pelos revoltosos. Nesse sentido, três pontos eram fundamentais, segundo sua análise: a) o envio de alimentos, especialmente leite, para suprir os bloqueios contra as retaguardas republicanas; b) uma pressão contínua sobre o governo britânico para forçar a revisão de sua política de "não alinhamento" e, c) o aumento da propaganda pró-republicana entre a opinião pública britânica para reforçar a luta antifascista. Para isso, Gollancz incitava os membros do LBC a participarem ativamente das campanhas promovidas pelos trabalhistas, das reunióes públicas e comícios, ou ajudar na organização de reuniôes para debater a situação espanhola onde ainda não houvesse um debate agendado ou mesmo para que cada membro do LBC - 50 mil à época - pudesse influenciar o círculo social ao seu redor. ${ }^{45} \mathrm{E}$ essa campanha resultou em frutos concretos: em janeiro de 1939, o número 33 da Left News anunciou a organização de um navio para envio de suprimentos para os republicanos, concretizado um mês depois, em fevereiro, para Barcelona. ${ }^{46}$

\footnotetext{
${ }^{45}$ Editorial by Victor Gollancz. Left News, n. 21, janeiro de 1938, p. 636.

${ }^{46}$ Left News, n. 33, janeiro de 1939.
} 
Mesmo depois da derrota dos republicanos em 1939, a Guerra Civil continuaria a ser tema das publicaçôes do LBC. Na década de 1940, outros dois livros tratariam da condição dos exilados da guerra em solo britânico. Um deles foi o livro de Thomas Jefferson Hamilton, Appeasement's child: the Franco Regime in Spain, publicado em 1943. Mesmo tema do último livro que o LBC publicaria sobre a Guerra Civil espanhola, Smouderling Freedom: the Story of the Spanish Republicans in Exile, de Isabel Oyarzábal, publicado em 1946, sobre o pseudônimo de "Isabel de Palencia".

Figura 8: Capa do n. 21, de janeiro de 1938, da revista Left News, ediçáo dedicada exclusivamente à Guerra Civil espanhola.

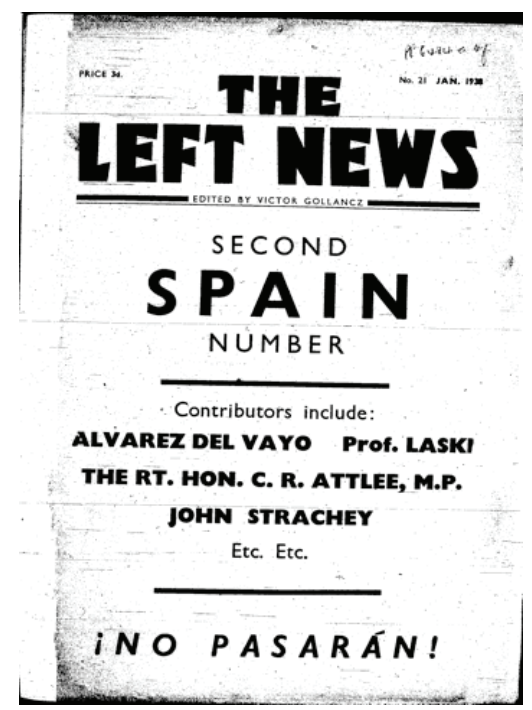

Fonte: Left Book Club Collection — University of Sheffield, Sheffield, Reino Unido. Catálogo disponível em: <http://www.shef.ac.uk/library/special/leftbook>.

\section{Considerações finais}

Com a Guerra Civil na Espanha, a polarização política internacional já atingia níveis suficientes para evidenciar aos britânicos que os mecanismos diplomáticos da Liga das Naçôes haviam fracassado - especialmente diante do total desdém de Hitler pela ordem e a paz internacional, haja visto os bombardeios da Luftwaffe no País Basco (na verdade, é preciso recordar, os mecanismos diplomáticos da Liga das Naçôes haviam se esgotado já em outubro 1933, quando a Alemanha se retira da Liga). Ficou claro também, como demostrou Angel Viñas, ${ }^{47}$ que a política isolacionista do governo britânico em relação à Espanha não passava de jogo de cena para encobrir os interesses comerciais estabelecidos em contratos que, segundo diplomatas britânicos, estavam em risco caso um governo socialista prevalecesse.

${ }^{47}$ VIÑAS, Angel. La conspiración del General Franco y otras revelaciones de uma Guerra civil desfigurada, op. cit. 
E os debates sobre os desdobramentos da guerra na Espanha que ocuparam largamente a opiniáo pública britânica entre 1936 até as vésperas da declaração de guerra da Grã-Bretanha à Alemanha, em 3 de setembro de 1939, serviram para mudar a perspectiva pacifista da opinião pública britânica, estabelecida desde o final da Primeira Guerra Mundial, e preparar os ingleses para o que estaria por vir. Os livros publicados pelo LBC em 1938, sobre a preparação das populaçóes civis para bombardeios aéreos, baseados nas experiências das equipes médicas britânicas no País Basco durante a Guerra Civil espanhola, prenunciavam o que Londres veria a partir de 7 de setembro 1940, quando começam os bombardeios diários da Luftwaffe à capital inglesa.

É interessante notar ainda que o grande experimento para a avaliação da opinião pública britânica daquele momento, o Mass Observation Movement, foi financiado diretamente pelo Left Book Club. ${ }^{48} \mathrm{O}$ projeto foi iniciado em Bolton, por Tom Harrisson e Charles Madge. Harrisson havia estudado novas formas de observação das condiçóes humanas através da pesquisa empírica. Para financiar o projeto, Harrisson pressionava Gollancz pela publicação de seu livro, Savage Civilization, pela Victor Gollancz Ltd, em cartas constantes e, às vezes, mal-educadas. ${ }^{49}$

Um dos estudos resultantes das pesquisas do Mass Observation foi o trabalho "Britain and the Mass Observation" (1939), e considerou a "alienaçâo do público comum para assuntos internacionais, e a tendência dos jornais em falar em nome do público sem considerar cientificamente suas opiniöes" ${ }^{50}$ Tom Buchanan argumenta que a experiência do Mass Observation, tanto quanto a atuação do LBC servem para indicar a mudança da opinião pública britânica em relação à Guerra Civil espanhola como parte da visão geral do público britânico na década de 1930 em relação à participação do governo local nos assuntos internacionais do período. O exemplo do Mass Observation serve ainda para avaliar de que maneira a opiniáo pública era formada política e ideologicamente na Grã-Bretanha dos anos de 1930 e como essa divisão representava um reflexo das divisóes da própria sociedade. $\mathrm{O}$ apoio massivo dos entrevistados em favor da República espanhola, por exemplo, não representava uma mobilização efetiva. Em contraste, o apoio às políticas de não intervenção do governo de Neville Chamberlain, a partir de sua eleição, em 1937, cresceu ainda mais em 1938, mesmo depois da anexação da Áustria e da Tchecoslováquia pela Alemanha nazista.

A explicação para essa confusão pode ser buscada no papel (político-ideológico) desempenhado pelos "formadores de opinião" daquela época — intelectuais, imprensa, órgãos

\footnotetext{
${ }^{48}$ Parte dos arquivos do Mass Observation Movement, assim como as atividades do Left Book Club em cidades do sul da Inglaterra, tais quais Bolton e Brighton, podem ser consultadas nos arquivos da University of Sussex, localizados no University of Sussex and Brighton and Hove Royal Pavilion Museum Records, University of Sussex, Sussex, Reino Unido. Agradeço a colaboraçáo do staff do The Keeper Archives, que guardam as coleçôes, em minhas pesquisas realizadas no mês de junho de 2015.

${ }^{49}$ HODGES, Sheila. Gollancz: The Story of a Publishing House, 1928-78, op. cit., p. 112.

${ }^{50}$ BUCHANAN, Tom. Britain and the Spanish Civil War, op. cit., p. 23. Grifo do autor.
} 
oficiais do governo etc. Quanto ao papel da imprensa britânica em relação à apreciação do público sobre os acontecimentos na Espanha, tema que fora largamente considerado, por exemplo, por George Orwell, ${ }^{51}$ Buchanan é enfático em considerar as divisóes sociais a que representavam: o The Times, como uma espécie de porta-voz oficial do governo britânico para os assuntos de relaçóes internacionais; o Daily Mail, o The Morning Post e o Observer, aos domingos, eram pró-Franco; à esquerda e pró-republicano (defendendo, porém, a não intervenção) estava o Daily Herald, como veículo em que o Labour Party expressava seu posicionamento; do lado liberal, o Manchester Guardian, o The News Chronicle e o Reynolds News, aos domingos - todos pró-republicanos e contrários à política de náo intervenção do governo. Todos os periódicos católicos eram pró-Franco; os jornais de influência anglicana ou da igreja livre declamavam neutralidade, enquanto apoiavam a náo intervenção (por fim, antirrepublicanos). Os semanários, com exceção do News Stateman e o Time and Tide, ambos à esquerda, defendiam neutralidade ou eram pró-Franco. Já a BBC, principalmente através do jornal corporativo The Listener, contrapunha os informes sobre o lado republicano com os informes sobre o lado nacionalista, classificado como "insurgente". Sem se aprofundar nos desdobramentos políticos da Espanha, os newsreels insistiam numa comparação entre o "arcaísmo" espanhol e o modo de vida britânico. Com isso, a imagem desenhada pela imprensa antirrepublicana tratava de assemelhar os acontecimentos àqueles de 1914, quando a ideia era exaltar a "barbaridade alemã" para o público local..$^{52}$

Nessa disputa de narrativas sobre a guerra na Espanha houve ainda o papel desempenhado por um livro publicado já em outubro de 1936, para definir a guerra civil como um "problema espanhol": The spanish tragedy, 1930-1937: Dictatorship, Republic, Chaos, Rebellion, War, de E. Allison Peers. Hispanista e professor de espanhol da University of Liverpool, Peers era considerado o maior especialista na área de seu tempo. E sua opinião foi rapidamente considerada a análise "neutra" de um ponto de vista acadêmico, mesmo que escrito por um ultracatólico e conservador. Em resumo, Peers apresentou o conflito como fruto das contradiçôes da sociedade espanhola, táo profundas que eram quase místicas e incompreensíveis ao público britânico. Seu livro teve boa aceitação, com o lançamento de seis ediçôes em meses e várias revisôes elogiosas. Esse é outro tópico enfatizado por Angel Viñas: o papel da historiografia estrangeira sobre a Guerra Civil espanhola, tanto dos poucos trabalhos publicados à época do conflito como aqueles lançados durante os anos do franquismo. $\mathrm{O}$ trabalho dos "hispanistas" — inclusive os anglófonos, tal qual Peers, mas também do esta-

\footnotetext{
${ }^{51}$ Sobre a crítica de Orwell à guerra de informações durante a Guerra Civil espanhola na imprensa britânica, ver, por exemplo, nosso trabalho anterior: "Memórias de uma guerra perdida: memória, identidade e imprensa na crítica orwelliana à repercussão da Guerra Civil espanhola, 1937-1942.” Apresentado no XIX Encontro Regional da Seção São Paulo da ANPUH, "Poder, Violência e Exclusão", em setembro de 2008, na Universidade de São Paulo, como parte da pesquisa para a dissertação de mestrado O último homem da Europa: a luta pela memória no universo não ficcional da obra de George Orwell, 1937-1949, defendida no Departamento de História da Universidade de São Paulo, em outubro de 2010. Pesquisa que contou com apoio da Fapesp. 52 BUCHANAN, Tom. Britain and the Spanish Civil War, op. cit., p. 25.
} 
dunidense Stanley Payne, um dos principais historiadores pró-franquista da Guerra Civil, ou britânicos como Raymond Carr, James Joll, Hugh Thomas etc. — foi fundamental para definir, especialmente durante o regime franquista, a "história da guerra civil". ${ }^{3}$

É possível entender então que os debates estrangeiros sobre a Guerra Civil espanhola, tal qual aquele desenrolado na opinião pública britânica - e pelo qual o Left Book Club contribuiu enormemente, difundido o tema por entre suas redes locais e internacionais ajudaram a chamar a atenção internacional para o conflito, o que, sem dúvida, favoreceu o engajamento de muitos estrangeiros - e não apenas britânicos - na Guerra. Fator que reforçou o fracasso da política de não intervenção adotada pelo governo britânico na guerra, desta forma, reconhecendo o perigo internacional do fascismo antes de estourar a Segunda Guerra Mundial.

\section{Fontes (Arquivos consultados em ordem alfabética)}

George Orwell Archive - University College London, Londres, Reino Unido. Catálogo. Disponível em: <https://www.ucl.ac.uk/library/special-collections/a-z/orwell>.

Left Book Club Collection (coleção da revista Left News) - University of Sheffield, Sheffield, Reino Unido. Catálogo. Disponível em: <http://www.shef.ac.uk/library/special/leftbook>.

Papers of Victor Gollancz - University of Warwick, Coventry, Reino Unido. Catálogo. Disponível em: <http://www2.warwick.ac.uk/services/library/mrc/holdings/>.

People's History Museum — Archive and Study Center, Manchester, Reino Unido. Catálogo. Disponível em: <http://www.phm.org.uk/archive-study-centre/>.

University of Sussex and Brighton and Hove Royal Pavilion Museum Records, University of Sussex, Sussex, Reino Unido.

\section{Referências bibliográficas}

BACZKO, Bronislaw. Imaginação social. In: Enciclopdia Einaudi, v. 5. Vila da Maia: Imprensa Nacional/Casa da Moeda, 1985, p. 333-396.

BERTONHA, João Fábio. Los fascismos en América Latina. Ecos europeos y valores nacionales en una perspectiva comparada. In: El fascismo en Brasil y América Latina. Ecos

\footnotetext{
53 Tópico que tive a oportunidade de comentar em resenha do livro de Vianãs (2011): Autor. VIAÑAS, Angel. La conspiración del general Franco y otras revelaciones acerca de una guerra civil desfigurada, op. cit. Rev. Hist. (São Paulo), São Paulo, n. 170, p. 351-360, jun. 2014. Disponível em: <http://www.scielo.br/ scielo.php?script=sci_arttext\&pid=S0034-83092014000100351\&lng=en\&nrm=iso>. Acesso em: 5 jan. 2017.
} 
Europeos y desarrollos autóctonos. México (DF): Instituto Nacional de Antropología e Historia, 2013.

BUCHANAN, Tom. The Death of Bob Smillie, the Spanish Civil War, and the Eclipse of the Independent Labour Party. The Historical Journal, v. 40, n. 2, p. 435-461, jun. 1997. Disponível em: <http://www.jstor.org/stable/2640074>. Acesso em: 12 abr. 2008.

. Britain and the Spanish Civil War. Nova York: Cambridge University Press, 1997. . Edge of darkness: British "front-line" diplomacy in the Spanish Civil War, 19371938. Contemporary European History, v. 12, n. 3, 2003.

CAPELATO, Maria Helena. Ensino primário franquista: os livros escolares como instrumento de doutrinação infantil. Revista Brasileira de História, Sáo Paulo, v. 29. n. 57, jan./jun., 2009, p. 117-145.

. Fascismo, uma ideia que circulou pela América Latina. In: SIMPÓSIO DA ASSOCIAÇÃO NACIONAL DE HISTÓRIA, 16., 1991, Rio de Janeiro, RJ. Anais..., p. 51-63.

CATÁLOGO Left Book Club Collection: Books published by the firm of Victor Gollancz on behalf of the Left Book Club 1936-1948. Dates: 1936-1948. Extent: 200 volumes plus, together with a art-set of "Left News". Special Collections \& Library Archives Left Book Collection. University of Sheffield, England. Disponível em: <http://www.shef.ac.uk/ library/special/leftbook.pdf>. Acesso em: 4 set. 2009.

CHARTIER, Roger. As origens cuturais da Revolução Francesa. São Paulo: Editora da Unesp, 2003.

. Os desafios da escrita. São Paulo: Editora da Unesp, 2002.

FERRO, Marc. A história vigiada. São Paulo: Martins Fontes, 1989.

HOBSBAWM, Eric. Os intelectuais e o anti-fascismo. In: HOBSBAWM, Eric et al. História do Marxismo. São Paulo: Paz e Terra, 1989, p. 257-314. v. 9.

HODGES, Sheila. Gollancz: The Story of a Publishing House, 1928-78. Londres: Littlehampton Book Services, 1979.

JOLL, James. Anarquismo e anarquistas. Lisboa: Dom Quixote, 1977.

LAITY, Paul. Left Book Club Anthology. Londres: Weidenfeld \& Nicolson, 2001.

LENIN, Vladimir. Speech at the Opening Session of the Congress. First Congress of the Communist International. 2 de março de 1919. Lenin Collected Works, v. 28, p. 455-477. Disponível em: <https://www.marxists.org/archive/lenin/index.htm>. Acesso em 12 jun. 2017. Lenin Internet Archive.

NADAL, Luis Urteaga Francesc; MURO, José Ignacio. La cartografia del Corpo di Truppe Volontarie, 1937-1939. Hispania, v. LXII/1, n. 210, p. 283-298, 2002. Disponível em: <http://hispania.revistas.csic.es/index.php/hispania/article/viewFile/273/275>. 
NORA, Pierre. Entre memóire et históire, la problématique des lieux. In: NORA, Pierre (Org.). Le lieux de memóire. Tome I (La Republic). Paris: Galllimard, 1984.

ORWELL, George. [The Road to Wiagn Pier] A caminho de Wigan. Rio de Janeiro: Nova Fronteira, 1986.

ORWELL, George. Complete Works of George Orwell. Peter Davison (Org.). Londres: Secker \& Warburg, v. 16, 1998.

. Lutando na Espanha, homenagem à Catalunha, recordando a guerra civil espanhola e outros escritos. São Paulo: Editora Globo, 2006.

. Orwell in Spain. Peter Davidon (Org.). Londres: Penguin Books, 2001.

ONSLOW, Sue. Cold War in Southern Africa: White Power, Black Liberation. Nova York: Routledge, 2009.

POLLAK, Michael. Memória e identidade social. Estudos históricos, v. 5, n. 10, 1992.

RODDEN, John. On the Political Sociology of Intellectuals: George Orwell and the London Left Intelligentsia of the 1930s. Canadian Journal of Sociology/Cahiers canadiens de sociologie, v. 15, n. 3, p. 251-273, Summer, 1990. Disponível em: <http://www.jstor.org/ stable/3340915>. Acesso em: 15 mar. 2008.

SARLO, Beatriz. Literatura y autoritarismo. In: MASSUH, Gabriela (Org.). Formas no politicas del autoritarismo. Buenos Aires: Goethe Institut, 1991.

SCHWARTZ, Fernando. La internacionalización de la Guerra Civil Española. Barcelona: Planeta, 1999.

SWITZER, Lew. South Africa's Alternative Press: Voices of Protest and Resistance, 1880-1960. Cambridge: Cambridge University Press, 1997.

THOMAS, Hugh. A Guerra Civil Espanhola. Rio de Janeiro: Civilização Brasileira, 1964. 2 v. THURLOW, R. Fascism in Britain. From Oswald Mosley's Blackshirts to the National Front. Londres: I.B. Tauris, 2006.

VIAÑAS, Angel. La conspiración del General Franco y otras revelaciones de una Guerra civil desfigurada. Barcelona: Critica, 2011.

\section{Como citar}

SILVA, Matheus Cardoso da. Ecos da Guerra Civil espanhola na Grã-Bretanha através das publicaçóes do Left Book Club. Topoi. Revista de História, Rio de Janeiro, v. 18, n. 36, p. 608-638, set./dez. 2017. Disponível em: <www.revistatopoi.org>. 